UDK 821.163-2.09"1876/1932":821.111-2.09 Shakespeare W.

\title{
WILLIAM SHAKESPEARE AND SLOVENE DRAMATISTS (II): J. JURČIČ, F. LEVSTIK, I. CANKAR, O. ŽUPANČIČ, B. KREFT (THE MAKERS OF MYTHS)
}

\author{
Mirko Jurak
}

\begin{abstract}
The purpose of this study is to explore the influence of William Shakespeare on Slovene playwrights in the period between 1876, which marks the appearance of Jurčič - Levstik's Tugomer, and the 1930s, when Oton Župančič published his tragedy Veronika Deseniška (Veronika of Desenice, 1924) and, a few years later, Bratko Kreft his history, Celjski grofje (The Counts of Celje, 1932). Together with Cankar's works all of the plays discussed in this study deal with one of the well-known Slovene myths.

In the previous number of Acta Neophilologica I published my study on the first Slovene tragedy Miss Jenny Love, which was published in Augsburg in 1780. ${ }^{1}$ The Romantic period, which followed this publication, was in Slovenia and elsewhere in Europe mainly characterized by the appearance of poetry, with a few exceptions of plays which were primarily intended for reading and not for the stage (Closet Drama). Let me mention here that in the Romantic period some of the finest Slovene poetry was written by France Prešeren (1800-1849), and although some of his friends suggested he should also attempt to write a play, his closest achievement to drama was his epic poem Krst pri Savici (Baptism at the Savica River, 1836), which is also often considered by literary historians as a predecessor of later Slovene dramatic literature.

Although many Slovene authors who wrote their works in the nineteenth century knew Shakespeare's plays, they still found it easier to express themselves in prose. The first Slovene novel is Josip Jurčič's Deseti brat (The Tenth Brother), which was published in 1866, ten years earlier than his play Tugomer (Tugomer). However, Jurčič's tragedy Tugomer was artistically very much improved by the adaptation made by Fran Levstik, whose text has been since considered as the "true" version of this play. Further editions and adaptations of this play definitely prove that several Slovene authors have found the subject-matter of this play worthy of new interpretations.

By the end of the nineteenth century the list of Slovene translators of Shakespeare's plays (most of them chose only some acts or scenes) was quite long. But it was only in 1899, when Ivan Cankar's translation of Hamlet appeared on stage of the Slovene National Theatre

\footnotetext{
${ }^{1}$ My sincere thanks are due for their help to the librarians of the Slavic Department of Languages and Literatures and to the librarians of the Department of Germanic Languages and Literatures, Faculty of Arts, University of Ljubljana; to the staff of the Slovene Theatre Museum, Ljubljana, and to Dr Jason Blake, Department of English, Faculty of Arts, University of Ljubljana.
} 
in Ljubljana, that a real master of the Slovene language approached one of Shakespeare's plays. Cankar became enthusiastic about Shakespeare's work and this is best seen also in Shakespeare's influence on three plays written by Cankar: Kralj na Betajnovi (The King of Betajnova, 1901), Pohujšanje v dolini Šentflorjanski (Scandal in the Valley of Saint Florian, 1907) and Lepa Vida (Beautiful Vida, 1911). The same kind of "enchantment" caught Oton Župančič, a Slovene poet, translator and dramatist, who had translated by 1924, when his Veronika Deseniška (Veronika of Desenice) appeared, several plays written by Shakespeare. A large number of echoes of Shakespeare's plays can be found in Župančič's play, not to mention the Bard's influence on Župančič's verse and style. Such influence can also be traced in Kreft's play.

Many Slovene literary historians and critics mention in their studies Shakespeare's influence on Slovene dramatists but their reports are mainly seminal and rather generalizing. Therefore the purpose of this study is to provide a deeper analytical insight into this topic.

Key words: William Shakespeare, his influence on Slovene dramatists (1867-1932): Josip Jurčič, Fran Levstik, Ivan Cankar, Oton Župančič, Bratko Kreft.

\section{INTRODUCTION}

In my article on William Shakespeare and Anton Tomaž Linhart's Miss Jenny Love, published in 2009 in Acta Neophilologica, ${ }^{2}$ I presented Shakespeare's influence on the first Slovene tragedy which was written by Linhart in 1780, and published in the same year. ${ }^{3}$ On the basis of numerous examples from this play I came to the conclusion that Shakespeare's influence on Linhart was much more important than had been previously believed. Although plays which I shall deal with in my present article have been discussed by a number of Slovene literary historians, the role of Shakespeare's influence on Slovene dramatists has often been neglected or rather generalized, made on personal impressions of critics than on the actual textual evidence from Shakespeare's plays.

After Linhart, and until the 1820s, there was no Slovene artist or critic who would call the attention of our readers to the Bard. But with the beginning of the Romantic period the situation changed quite rapidly and since then there was hardly a Slovene author or critic who would not mention William Shakespeare and his work, either in his own writing, or in his articles, letters, or diaries. In the Romantic period the predominant literary genre in Slovene literature was - like in a number of other European literatures - poetry. With the advancement of realism, the short story and the historical novel, in the second half

\footnotetext{
${ }^{2}$ Jurak (2009, 3-43). - I have included in my text brief summaries of plays which I discuss in my study in order to provide the basic reference for non-Slovene readers.

- Unless otherwise stated the translations from Slovene into English and vice versa were made by the author of this article. Some titles of Slovene literary works have appeared in English in various versions; in such cases I accepted one of them (or, in a few cases, coined a new English title).

${ }^{3}$ Anton Tomaž Linhart (1756-1795), dramatist, historian, poet. His first play Miss Jenny Love was written in German and published in Augsburg, Germany in 1780. It was first performed in Slovene on 20 October 1967 at the Slovene National Theatre (SNT) in Ljubljana. Linhart's fame rests on his comedies: Županova Micka (Molly, the Mayor's Daughter, performed in 1789 by the SNT) and on Ta veseli dan ali Matiček se ženi (This Happy day, or Matiček Gets Married, which was printed together with his first comedy in 1790 but, due to the censorship in the Hapsburg monarchy, not performed until 1848.). My analysis of Linhart's play Miss Jenny Love and particularly of Shakespeare's influence on Linhart can be found in the above mentioned study.
} 
of the nineteenth century these genres acquired a much greater popularity than dramatic art. Although the greatest Slovene poet, France Prešeren (1800-1849), mentions Romeo and Juliet in his poem "Nova pisarija" (A new kind of writing), he did not translate into Slovene, for example, any of Shakespeare's sonnets or scenes from his plays, though he did translate into Slovene the first 233 lines of Byron's little known poetic tale "Parisina". In the 1820s Prešeren was advised by his friends to write "a Romantic tragedy from Carniola", but his love for poetry prevailed and he did not feel ready to write a play on a historical subject (Paternu 1976, 1977). Even though echoes of Shakespeare's dramatic style may be noticed in Prešeren's epic poem "Krst pri Savici" (Baptism at the Savica River) - particularly in Prešeren's use of comparisons and metaphors (Koblar 1965: 144-5) - Prešeren never took to drama. His friend Matija Čop had an excellent library including a number of books written by English authors, e.g. by Thomas Moore, John Milton, Oliver Goldsmith, Lord Byron etc. as well as thirteen plays (!) written by Shakespeare. One of the reasons why Prešeren did not accept this challenge may also be that he had to worry about earning money before he finally obtained a solicitor's position (after all, poems take less time to be written than plays). As he was one of Čop's closest friends there is no doubt that Prešeren had easy access to the Bard's work. We should also remember that this was the period when European artists greatly admired the work and ideas embodied in the poems of Lord Byron, John Keats and P. B. Shelley. Although some English literary historians believe that in the first half of the nineteenth century "Byron's poetry was greeted with an enthusiasm which his genius alone did not deserve" and that "poetry written by Wordsworth constitutes the most important literary phenomenon of the time" (Jack 1963: 2), the fact remains that at that time most European artists and intellectuals interested in literature primarily admired poems written by English Romantic poets. I believe that this was also mainly due to their passionate struggle for democratic ideals, for a free individual as well as for the freedom and independence of nations. If we accept this conclusion we may more easily understand not only the development of Slovene but also of European drama of the nineteenth century. In 1848 the leading Slovene political programme became the newly-established United Slovenia, a programme which was in many ways very much like similar programmes of other central European countries in which nations were not yet free and independent.

The first Slovene translations of individual scenes from Shakespeare's plays began to appear in various journal and periodicals in the 1850s. Some years later Slovene critics also began to publish their own essays on Shakespeare and towards the end of the nineteenth century their number constantly increased (Moravec 1974: 341-71). At this time several Slovene critics and artists also expressed their wish that all of Shakespeare's plays be translated into Slovene, but this was a difficult task, which could only be realized one hundred years later. Shakespeare's first play to be performed by the Slovene Dramatic Society (established in Ljubljana in 1867) was Othello, which was staged on March 3, 1896. Hamlet, which in the first half of the twentieth century became Shakespeare's most popular play in Slovenia and was often referred to as "our folk play", was first produced in Slovene three years later, on December 27, 1899, by the Drama of the Slovene National Theatre of Ljubljana (abr. as the SNG Drama). ${ }^{4}$

${ }^{4}$ The information regarding the programme of Slovene theatres since 1867 is available in Repertoar slovenskih gledališč, 1867-1967 (A Repertoire of Slovenian Theatres, 1867-1967, published by the Slovenski 
It should be mentioned though that since the sixteenth century citizens of Ljubljana had many opportunities to see plays performed mainly by German and Austrian travelling theatre companies. Several companies also performed plays written by Shakespeare, or, as was common until the beginning of the nineteenth century also elsewhere in Europe, they performed adaptations of Shakespeare's plays. Productions prepared by students of the Jesuit College in Ljubljana reach back to the seventeenth century when these students also performed an adaptation of King Lear. Their activities were important for Slovene population, because "the Jesuits also used the vernacular, Slovene language, besides Latin and German". ${ }^{5}$ Many Slovene students who studied in Vienna during the past few centuries saw Shakespeare's plays performed there. These intellectuals often brought back to Slovenia his plays printed either in English or in other European languages. They also wrote about them in their letters to their friends across Europe, and reported about them in their articles and essays published in Slovenia and abroad.

\section{THE THREE VERSIONS OF TUGOMER}

- JOSIP JURČIČ: Tugomer (Ms. writ. in 1875; publ. in 1960). ${ }^{6}$

- JOSIP JURČIČ and FRAN LEVSTIK: Tugomer (writ. and publ. in 1876. In this edition only Jurčič was mentioned as the author of the play although nowadays Slovene literary historians believe that this revised version of Jurčič's play is mainly Levstik's work.) The play was first performed on 6 Feb. 1919 by the SNG Drama in Ljubljana; still with Josip Jurčič mentioned as the only author.

- FRAN LEVSTIK and BRATKO KREFT: Tugomer (Levstik's version adapted by Kreft.) It was first performed on 25 Oct. 1947 by SNG Drama in Ljubljana; publ. in 1967).

The reason why the first classical Slovene tragedy was written in several versions is the result of the artistic problems with which the first author of Tugomer,

gledališki muzej, Ljubljana, 1967). Subsequent bibliographical compilations were published at first every five years as Dokumenti slovenskega gledališkega muzeja (Documents of the Slovene Theatre Museum) and, since 1993, annually under the title Slovenski gledališki letopis (Slovene Theatre Annual).

${ }^{5}$ Grošelj 2004: 61-71.

${ }^{6}$ Josip Jurčič (1844-1881), novelist, dramatist, journalist. Writer of historical novels, admirer of Walter Scott. He wrote the first (prose) version of Tugomer (MS) in 1875, but this edition was published only in 1960.

- Fran Levstik (1831-1878), poet, novelist, dramatist, critic, journalist. With his essay Potovanje iz Litije do Čateža (The Journey from Litija to Čatež, 1858) he influenced Josip Jurčičs's views on literature. He completely revised Jurčič's version of Tugomer, although the play was first published in 1876 only under Jurčič's name.

- Bratko Kreft (1905-1996), novelist, dramatist, theatre director, literary historian. His best known histories are Celjski grofje (The Counts of Celje, 1932) and Velika puntarija (The Great Rebellion, 1937). He adapted Levstik's version of Tugomer for the stage, trying to follow in it the structure of Shakespeare's histories, several of which he produced at the SNG Drama in Ljubljana. 
Josip Jurčič, was faced. He began to write Tugomer in trochaic verse, but his friend and his literary mentor Fran Levstik advised him to use iambic pentameters, which would suit the tragedy better. But Jurčič obviously could not realize this idea without help and so he wrote the first version of Tugomer in prose (it appeared in print only in 1960). Levstik offered Jurčič his help and the first printed version (based on Levstik's adaptation in iambic verse) was published already in 1876, but with only Jurčič's name mentioned as its author. Slovene literary historians (e.g. Anton Slodnjak, Mirko Rupel, France Koblar etc.) agree that this version of Tugomer was basically Levstik's work.

Due to the censorship of the Hapsburg regime, the play was not allowed to be performed in Slovene theatres until 1919, when Slovenia became a part of Yugoslavia. Kreft's version of Levstik's text, which was performed after the Second World War, was intended to make the play theatrically more vivid and structurally more in accordance with Shakespeare's histories and great tragedies.

The main source for Jurčič's version of Tugomer was a description about the fighting between the Franks and the Wends in the tenth century. It is presented in Ludwig Giesebrecht's book Wendische Geschichten aus den Jahren 780 bis 1182 (The History of the Wends from 780 to 1182, publ. in Berlin in 1843). This short account (ibid. I, 142) was used by Jurčič as a parallel between the germanization of the Wends (the Slavic people occupying the region between the Elbe and Oder rivers in the eastern part of Germany) with the contemporary pressure of the Austrian empire on the Slovenes in the second half of the nineteenth century. Giesebrecht's historical account is quoted by Mirko Rupel in Jurčič's collected works (ZD IX, 1960: 270-71). In the German legend and in the first (Jurčič's) prose version of Tugomer, the hero is presented as a traitor who betrays his people because he is obsessed by his erotic feelings for Zorislava, the widow of the former Slovene duke Čeligoj. When Tugomer's treason and his murder of Čeligoj become known, Zorislava kills him. In Levstik's version Tugomer is presented as an idealist, who trusts the Franks and who is also himself betrayed by his "friends". Whereas Jurčič's version is centred on the weaknesses of Tugomer's character Levstik stressed in his version the drama of ideas: a naive leader, who wishes to stop the wars between the Franks and the Slavs, unwillingly betrays his people.

Josip Jurčič knew Raphael Holinshed's Chronicles of England, Scotland, and Ireland (1587) from which Shakespeare took plots for his historical plays. When Jurčič was in Vienna (1865-1867) he studied Shakespeare and his plays ${ }^{7}$ upon the advice of his friend and his literary mentor Fran Levstik and it was then when he began to think about writing a historical play. He wished to show in it how the discord among the Slavic people and the ambitiousness of their leaders bring disaster to the whole nation. It is obvious that Jurčič was enthusiatic about Shakespeare's work, for in Jurčič's best known novel, Deseti brat (The Tenth Brother, 1866), the narrator exclaims: "Oh, thou, great Shakespeare, the man of wisdom and knowledge". He adds that Shakespeare could not have thought, even in his dreams, that three hundred years later a person from Illyria

\footnotetext{
${ }^{7}$ Jurčič mentions in his notes a study written by G. G. Gervinius, Shakespeare I, II (Leipzig 1848, 1850). - His notes are kept at the National and University Library in Ljubljana.
} 
would reach his highness. ${ }^{8}$ Jurčič was an important Slovene journalist and in his articles he appealed to young writers to learn how to write by reading works written by great masters, among whom he explicitly mentions Shakespeare. ${ }^{9}$

We can also find references to Shakespeare's plays in Levstik's articles. So, for example, in one of his early works Levstik paraphrased Hamlet's words on the purpose of playing: "The poet's work should be the mirror of his time, it should be the cornerstone of national life, otherwise it is of no value, it is like a building built on a spider's web" ${ }^{10}$ In the same essay Levstik stresses the need to establish a Slovene theatre which would not present only stories dealing with lives of peasants but also other subjects. $\mathrm{He}$ stresses in this essay that historical plays should be written in such a manner which did not demand "the knowledge ... of particular historical sources". ${ }^{11}$ This suggestion can be linked with Aristotle's statement in his Poetics (ch. 9), according to which the making of the poet is "not to speak of incidents which have come to be, but rather of incidents which might come to be ... for making speaks more of universals while history speaks more of particulars" (Aristotle 17). Levstik also made a clear distinction between the ethical and the aesthetic components of a play: he states that even "a great criminal, like Shakespeare's Richard III, who is physically a handicapped person, is nevertheless a beautiful aesthetic character, aesthetic, but not moral" (Levstik 1955: 389). Levstik stresses Shakespeare's artistic greatness particularly if it is compared with the knowledge (writing) of a historian; a view about his talent which had been so well expressed before in John Dryden's evaluation of Shakespeare. ${ }^{12}$ We may conclude that in the second half of the nineteenth century William Shakespeare was considered by Slovene artists and critics as one of the most important European artists of all times and that his influence on Slovene writers was considered as most positive.

An important Slovene critic and writer in the second half of the nineteenth century was also Josip Stritar. He was not enthusiastic when the provincial assembly of Carniola issued in 1870 an award for an original Slovene historical drama; he suggested that the competition should be open to all dramatic genres, because even among Shakespeare's plays his historical works (on English national history) are not placed among his most important works. ${ }^{13}$ Stritar advocates the aesthetic autonomy of the arts, and he adds that if such a limitation as prescribed by the Slovene provincial assembly were imposed on Shakespeare then even "this great man" could not receive such an award although he wrote such plays as Hamlet, Othello, Romeo and Juliet, Julius Caesar. Stritar also mentions Shakespeare as a great author as compared with Byron, Prešeren, Dante,

\footnotetext{
${ }^{8}$ Jurčič's reference is to the Illyrians, an ancient people, who lived in the country along the eastern part of the Adriatic Sea, which became in 168 A.D. a Roman province (Illiricum). During Napoleon's reign (1809-1813) the Illyrian provinces, which were set up by Napoleon, included parts of Carniola and Carinthia (i.e. of present day Slovenia) and their capital was Ljubljana. This is why Jurčič refers here to the reader, Manica ("a person from Illyria"), who reads Shakespeare's Hamlet. (Shakespeare's comedy Twelfth Night; Or, What You Will is also set in Illyria.)

${ }_{9}$ Štefan Barbarič, Josip Jurčič. Znameniti Slovenci. Ljubljana: Partizanska knjiga, 1986: 119.

${ }^{10}$ Fran Levstik, "Potovanje iz Litije do Čateža" (The Journey from Litija to Čatež"), ZD IV, 1954: 27.

${ }^{11}$ Qtd. by Mirko Rupel in Jurčič ZD IX, 1960: 267. - Zbrano delo = Collected Works, abbr. as ZD.

${ }^{12}$ Aristotle 17. - Dryden's evaluation of Shakespeare is also quoted in Jurak 2009: 12.

${ }^{13}$ Josip Stritar (1836-1923), poet, writer, critic. He was one of the editors of the magazine Zvon for which he wrote a number of critical essays. He advocated "the freedom of the arts", their autonomy, in his "conversations" and in his "critical letters" in his review Zvon (e.g. on 15 March 1870).
} 
Goethe, Aeschylus, Sophocles, Calderon, Molière etc. ${ }^{14}$ which undoubtedly shows his great admiration of the Bard.

Slovene literary historian France Koblar surmises that Jurčič was stimulated to write Tugomer by the above mentioned competition (Koblar 1972: 90). Several minor Slovene dramatists also wrote plays on a historical subject during the final decades of the nineteenth century, for example, Ivan Robida wrote the historical play Erazem Tattenbach and Anton Medved Viljem Ostrovrhar. ${ }^{15}$ The writer's decision to write about historical figures was probably the result of the increased awareness of Slovene national consciousness in this period.

In the twentieth century Shakespeare's plays were often directed in the Slovene National Theatre in Ljubljana by Bratko Kreft. He also edited for publication the new Levstik's version of Tugomer, in which he mainly preserved Levstik's text, and he directed this version of Tugomer in the SNG Drama in Ljubljana in 1947. He also wrote a preface to this publication and he stressed in it that Levstik's play reflects Shakespeare's humanistic ideas as well as political, national and ethical ideals expressed by Lessing and Schiller. ${ }^{16}$

Dušan Moravec summarizes in his study on Shakespeare in Slovenia views expressed by Slovene literary historians and critics by saying that they see Shakespeare's influence on Tugomer in its verse, form and structure (1974: 346). He points out that already in 1932 Anton Slodnjak observed how Levstik had taken away from Jurčič's version all the Romantic, erotic connotations, and at the same time made the play sound more archaic by his acceptance of Shakespeare's dramatic technique. Moravec also mentions Koblar's afterword published in the Levstik and Kreft's edition in which Koblar states that even in Jurčič's first version some elements containing "Shakespeare's horror and picturesqueness" may be seen. As I have already pointed out above Slovene literary historians agree that the first published version of Jurčič's Tugomer, which is written in blank verse, is basically Levstik's work. Koblar also stresses in his essay that ideas which were relevant for Slovene history in the nineteenth century, i.e. the question of national independence and the unity of the Slovenes, became the core of this tragedy. Matjaž Kmecl states in his recently published study on Josip Jurčič that there are two versions of Tugomer, the romantic and the classicist version; the first one written by Josip Jurčič, which presents the tragedy of the hero's character, and the second one by Fran Levstik, which presents national - psychological aspects of this play. (Kmecl 2009: 122-125) This can be a solution to the dispute regarding the "true" authorship of this play.

Several Slovene literary historians (e.g. Mirko Rupel, France Koblar etc.) also mention that in Jurčič's and in Levstik's versions of Tugomer the influence of Shakespeare's histories and tragedies can be seen. Janko Kos suggests that Shakespeare's Coriolanus presents the most direct pattern for Levstik's Tugomer, although he admits that "there is a considerable difference between the two heroes" (2001:193-94), because

${ }^{14}$ Josip Stritar (ZD VI, 1955: 16, 18, 141). He compares Shakespeare to Aeschylus, Dante, Calderon etc. in whose works "the truth is discovered in the most beautiful image" when poetry and philosophy, beauty and truth form a unique union. He calls these authors "poets and prophets." (ibid. 60).

${ }^{15}$ Ivan Robida (1871-1941) and Anton Medved (1869-1910) are rather minor literary figures. France Koblar (1972: 150-163) compares Robida's hero with Shakespeare's Iago, and he finds in Ostrovrhar several motifs which could be linked with Shakespeare's plays.

${ }^{16}$ Fran Levstik, Bratko Kreft. Tugomer (1967: 22-3). 
Levstik's hero is "indebted to the pre-Romantic classical tragedy", and particularly to Schiller, what Bratko Kreft had also mentioned (see above). According to Kos the Roman leader Coriolanus is a mentally unstable hero who betrays his people because of his egotism and his aristocratic nature. However, one should not forget that Coriolanus finally reaffirms his love for Rome, though he pays for his betrayal of the Romans and his support of the Volscians with his life. Kos does not see Levstik's Tugomer as an extremely proud character (like Coriolanus), although he also sees in Levstik's character his good sides and his noble nature. Further on, Kos finds parallels between Coriolanus and Tugomer with regard to their attitudes to their mothers and to their wives, as well as to their compatriots (the Romans and the Slavs), and to their opponents (i.e. to the Volscians and to the Franks). But he points out that Tugomer's relationship to his people is different from that of Coriolanus, because Tugomer never transgresses the border line between himself and his people.

The interpretation provided by Janko Kos places Coriolanus as the major, the most important Shakespeare's play to have influenced Levstik's Tugomer. But if we analyse and compare both plays in detail we see that there are also a number of important differences between both plays and that Coriolanus is not likely to be the only major influence on (different versions) of Tugomer and that this influence has been over-estimated. First of all, Coriolanus and Tugomer come from a completely different political, historical and social background: Coriolanus is a victorious Roman leader who has won several battles against the Volscians and their general Aufidius, but because his dignity is questioned by his Roman opponents he reacts with pride and stubbornness; he leaves Rome and joins his opponents, the Volscians. Coriolanus does not attack Rome because his mother Volumnia asks him not "to tread on thy country's ruin, / And bear the palm for having bravely shed / Thy wife and children's blood" (Cor. 5.3.16-18).

On the other side Tugomer is in a completely different position: in Jurčič's text he is in love with Zorislava and hopes to marry her. In this version she is a domineering, ambitious woman, almost like Lady Macbeth. Therefore when Zorislava learns that Tugomer had killed her husband, she stabs him (5.9). In Levstik's poetic version (5.8) as well as in Levstik-Kreft's version (5.3), Tugomer never intends to subdue his own people and he dies in the embrace of his loving wife Zorislava. Besides, Slovene playwrights do not present Tugomer as a man who is so completely overcome with his ambition as Coriolanus, but his main desire is to help his own country to become independent so that the Slavs could live in peace and therefore he wishes to settle the political and the military tensions between the Franks and the Slavs. Tugomer leads a "just war" by protecting his people and their land and not a war to defeat and govern another nation. ${ }^{17}$ Although in Levstik's version Gripo, who is a German settler among the Slavs, tells Tugomer that he will be offered the crown - which really happens -

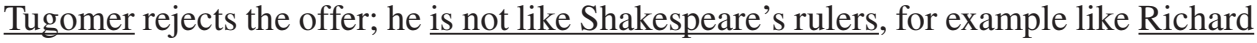
III or Julius Caesar, whose rejection of the crown is only seeming and they actually wish to wear the crown. Tugomer is the military leader who fights for the liberty of his people, and not for his own fame. In Levstik - Kreft's version Gripo's suggestion that

\footnotetext{
${ }^{17}$ See the interpretation regarding the treatment of war in Shakespeare's plays in the study published by Paola Pugliatti, Shakespeare and the Just War Tradition (Farnham, Surrey, Ashgate Publ. Co., 2010).
} 
Tugomer should accept the crown is made in order to bring discord among the Slavs (2.2). However, Tugomer is naive and he believes at first that a Slavic king would actually bring his people the "benefit and blessing" even if he is selected by the Franks. But he is mistaken what is proven by the duke of the Franks, Geron, who expresses his hope that his offer to crown Tugomer will create in Tugomer a craving for fame (2.5) and force him to become dependent on the Franks. But when Tugomer realizes that this offer is really a trap, he tells Geron that he will never buy "the vassal's crown" with the bloodshed of his own people (3.6). In Levstik - Krefts's version Tugomer admits to his friend Bojan that if he had ever thought about the royal sceptre the only reason was that in his view his leadership would be more firm and would bring freedom to his people (Levstik - Kreft 1967: 164). In this version Tugomer finally entrusts the dukedom to another tribal leader, Mestislav, and appeals to him to raise all the Slavs against their enemy (ibid. 171). Mestislav sees Tugomer as an honest, proud Slavic warrior and he tells other Slavic military leaders that "Tugomer was the bravest of them all in their battle against the Franks". In Act 5, Scene 3, just before his death, Tugomer tells his son to be "a man made of steel, when he has to defend the honour of his nation, its rights and its language" (ibid. 188). These thoughts and actions link the text in the final Levstik - Kreft's version much more to Shakespeare's early chronicle plays than to his late tragedies.

Coriolanus wishes to diminish his excessive ambitiousness and so he tries to excuse his joining the Volscians by his "fight / Against my cank'red country" (4.5.93-4). Tugomer also implicitly accepts faults which are obvious in his people (e.g. their lack of unity), but he hopes that his efforts to make peace with the Franks will be successful and that the Slavic people would thus become equal to the Franks. When Levstik's Tugomer is mortally wounded and he sees that he was betrayed by the Franks he tells his people "to defend vigorously the honour of their country, the rights of its people and their language" (5.8). The difference between the fate of the Romans in Coriolanus and the fate of the Slavs in Tugomer is also important: whereas the Romans are (already) a free nation, the Slavs still have to fight in order to gain their freedom. In Levstik's eyes the fate of the Slavs in his play and the historical reality with which the Slovenes were faced in the nineteenth century, is the same: their future is rather uncertain and therefore they should neither naively mislead themselves as regards the relations between them and the Franks nor should they allow to be misled by their enemies (Levstik ZD V; 1955: 209). Coriolanus pays for his tragic opposition to his own people with his death (his former and his real enemies, the Volscians, kill him), whereas Tugomer is killed in his fight with the Franks. The playwright shows that Tugomer was naive and trustworthy enough to have brought his best men to his enemies' camp, where the Slavic leaders with the exception of Tugomer - were killed. But when Tugomer sees how he had been betrayed by the Franks he starts to fight with the Franks and dies a hero. In Tugomer (Act 5) both ordinary Slavic soldiers as well as their military leaders and even the Franks praise Tugomer's decisive role in this battle, which can be compared in its meaning and importance with the battle between King Henry the Fifth and the French. King Henry tells his cousin Westmoreland and his soldiers that he is "not covetous for gold", but that he wishes to defend his honour and his country and he invites the English soldiers to fight with him: 
This day is called the feast of Crispian;

He that outlives this day, and comes safe home,

Will stand a tip-toe when this day is named

And rouse him at the name of Crispian. (King Henry V, 4.3.40-44)

He tells his soldiers that they will always remember this day, they will be proud of the scars which they got in this battle and they will also be always remembered. They who remain alive will be his "brothers", and those who are not present will feel cursed for not having been there. Tugomer also tells his friend Bojan that what he always had in mind was the welfare of his country and not his own profit (Levstik ZD V 1955: 185).

In Levstik - Kreft's version Tugomer appeals to his soldiers to fight bravely for their country in a very similar way to that we find in Shakespeare's King Henry $V$. The similarity between the patriotic struggle of English soldiers against the French in Shakespeare's historical play and the battle fought by Tugomer's soldiers against the Franks does not appear to be incidental and we may justly surmise that both authors, Jurčič and Levstik, may have had in mind the scene from this play written by Shakespeare when they wrote about the fighting between the Slavs and the Franks.

Tugomer's political programme is clear: the Slavs should endeavour to establish peace with the Franks but in order to achieve this they should first be united. This, however, does not happen. In Shakespeare's histories justice finally wins, the legal order is established again and the power of the people is vested in a character who can claim legal rights for his rule. In Coriolanus the Romans remain free, whereas in Tugomer the future of the Slavs remains uncertain although Levstik views it with optimism. We can conclude that even though there are certain thematic parallels between Coriolanus and Tugomer both plays differ in a number of significant aspects and that therefore Coriolanus cannot present the main parallel between Shakespeare's plays and Levstik's Tugomer. Both authors, Jurčič and Levstik, must have either read some of Shakespeare's histories, for example King Henry V, or they were at least informed about their plots from sources about English literature they had known.

There are also some other parallels between Shakespeare's plays and Levstik's Tugomer that have not been fully discussed yet. Among structural parallels between Shakespeare's plays and this play Slovene critics most often mention the introductory $\underline{\text { scenes }}$ in which less important characters appear first. These characters function as the

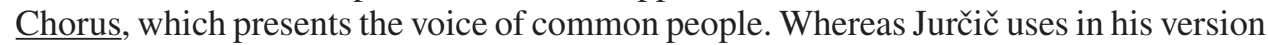
of the play two minor characters, in Levstik's version such "chorus" scenes include at least three characters (e.g. three old men in 1.1, 1.2, 2.1, 4.2), or a whole group of people (e.g. the citizens of Branibor: 1.5, 1.6, 4.1, 4.5), or even all the characters who represent public opinion and are present on the stage (e.g. a group of senior citizens in 2.6; etc.). Such Chorus scenes involving several or a group of people remind us of similar scenes in Shakespeare's histories, e.g. in King Henry V, in Coriolanus and in Hamlet.

The elements of superstition should also be mentioned as a similarity between Shakespeare's plays and Tugomer. The Slavic pagan priest Zovolj, who is almost completely blind, foretells the future war between the Franks and the Slavs. He is like the Soothsayer in Shakespeare's Julius Caesar $(1.2,3.1)$. In the final scene of Levstik's Tugomer (5.10) Zovolj, for instance, announces the revenge of the Slavs on the Franks and the future freedom of the Slavs. The dramatists' presentation of aggressive and 
treacherous Franks and Tugomer's appeal to the Slavs to be brave and to defend the honour of their nation and their language $(5,3)$ was most likely the main reason why the play could not be produced in Slovenia during Hapsburg rule. On the other hand, patriotic ideas expressed by English kings and other warriors in Shakespeare's histories were not questioned in the Hapsburg Empire and were accepted as a fact.

In both versions of Tugomer obvious omens indicate the tragic future of the Slavic people. So, for example, in the introductory scene of Tugomer the three old men mention the signs which prophesy the future battles and which are seen in nature, as e.g. the cranes unexpectedly flying towards the south; the ravens which suddenly appear everywhere; the red sky at night; the fiery horse-riders seen by ordinary men on the clouds (1.3). In Julius Caesar Casca tells Cicero that he is moved because "all the sway of earth / Shakes like a thing unfirm" (1.3.3-4); or, that he walked "through a tempest dropping fire" (1.3.10), and that "the bird of night did sit / Even at noon-day upon the market-place, / Hooting and shrieking." (1.3.26-28) Similarity between Shakespeare's and Levstik's imagery is obvious. There are also a number of similar cases which are known from superstitions spread by folk tradition. For example, Tugomer's grandmother Vrza is subject to hallucinations (like lady Macbeth or like Volumnia in Coriolanus); she sees at her bedside the bloody hands of her son's murderer (2. 11,.12); at the end of the battle a black cat crosses her path and Vrza hears the shrieking voices of ravens (5.3). Before his death Tugomer hears the voices of the dead Slavic soldiers whom he had delivered to the Franks (5.3), just as Shakespeare's heroes are troubled by the voices of people whom they had killed (e.g. in Julius Caesar, 4.3; 5.5, in Richard III, 5.3, in Macbeth 3.4). Further on, in the battle between Tugomer and Gripo (a Frank who used to live among the Slavs and wished to marry Tugomer's sister Grozdana) Tugomer kills Gripo's horse so that Gripo cannot escape and then he conquers Gripo in the duel (just as Richard's horse is killed first and then Richard is slain by the Earl of Richmond, 5.4, 5.5). Geron, the duke of the Franks, tells his soldiers that Tugomer had cut off Gripo's head (5.9) and that he put it on a pole, just like Macduff did after he had slain Macbeth 5.9). Such obvious similarities between scenes in Shakespeare's plays and Levstik's Tugomer clearly indicate that Slovene authors were under the impact of Shakespeare's dramatic solutions.

Tugomer delivers his final speech before his death in the presence of his wife Zorislava and his friend Bojan (5.3). The subject of his speech is very much like Hamlet's final message: people should learn the truth about the past of their ancestors. Tugomer's speech is longer than Hamlet's monologue because he also presents in it his political programme. He appeals to the Slavs that they should be obdurate and inexorable when their honour, their rights and their language are in question; they should not delude themselves about the reality, and they should not allow themselves to be cheated by their enemies but they should fight for their rights to the last drop of their blood. But, in order to be free, the Slavs should "no longer be mad", they should not fight among themselves, but they should unite. This kind of appeal was also delivered by Henry, the Earl of Richmond (afterwards King Henry VII), who demands from his fellow-men in

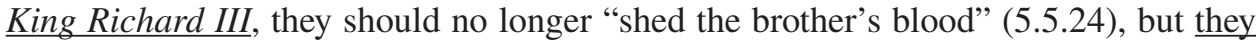
should unite (just like York and Lancaster, the white and the red rose). When the battle ends Richmond asks Lord Stanley: "What men of name are slain on either side?" 
Stanley tells him the names of leaders killed on both sides, and then Richmond gives an order: "Inter their bodies as becomes their births. / Proclaim a pardon to the soldiers fled / That in submission will return to us: ... We will unite the white rose and the red." (5.5.12-19). Richmond is not like Richard III, for whom "Conscience is but a word that cowards use" (5.3.309), and therefore the peace and unity which Richmond brings to the English will have a lasting effect. As I have indicated above, the scene which refers to the historical tensions between the Slavs and the Franks in Tugomer was most probably one of the main reasons why at the time when Slovenia was a part of the Hapsburg Empire the authorities did not allow the play to be performed. It should be noted though that Levstik presented Geron, the duke of the Franks, as a military leader who shows respect to the dead on both sides. The portrayal of Geron in the final scene in Tugomer reminds us of Fortinbras in Hamlet, who also orders that "the soldier's music and the rite of war / [should] Speak loudly for him" (5.2).

Coriolanus and Tugomer have almost identical attitudes to the mob: they despise it, because they know that it reacts spontaneously and emotionally, without thinking and without taking into consideration the rational reasons which have brought about a certain situation. Tugomer is definitely a more naive character than Coriolanus. He hopes that he can turn the mob from its own animosity to the perspective positive for the whole nation, to fight for their freedom. Although Kos mentions in connection with possible Shakespeare influence primarily Coriolanus, both Jurčič and Levstik must have also known other Shakespeare's heroes with a similar attitude to the mob, particularly $\underline{\text { Julius }}$ Caesar and Richard III. Shakespeare's multi-layered language as well as his presentation of characters provides such an abundance of examples that it is sometimes difficult to establish the primary or the most relevant possible source of a comparison. However, in some cases such parallels may also be the result of similar human attitudes to certain situations and problems and/or common linguistic practice in both languages; they may simply reveal the general human experience as it was expressed by means of language in a given historical period.

In Jurčič's prose version Tugomer is in love with Zorislava. She is the widow of the former Slavic leader Čeligoj, whom Tugomer had murdered in order to win her for himself. Tugomer, Zorislava, and the murdered Čeligoj thus form a triangle which resembles king Claudius, Queen Gertrude and her dead husband (Old Hamlet) in Shakespeare's Hamlet. Although Jurčič's Tugomer's is tortured by his conscience (like Claudius), Tugomer does not admit his crime to Zorislava, because he wants to marry her (and neither does Claudius for the same reason). However, Zorislava rejects his proposal, because she does not love him enough and she does not respect him as much she had respected her former husband. She is also shown as a much more honest and devoted female figure than Gertrude. Kmecl suggests in his study mentioned above (Kmecl 2009: 126) that Jurčič's portrayal of Tugomer is close to that of Othello: his eroticism prevails over everything else and his increased ambivalence of love and hatred pushes him and everybody who is close to him to destruction. As attractive as this suggestion might be, we should not forget that there are also many dissimilarities between both heroes. Othello is a noble warrior whereas Zorislava accuses Tugomer of not being brave enough to oppose the Franks, and she therefore does not respect him (this is not the case with Desdemona). Besides, Desdemona loves Othello; Zorislava in 
Jurčič's Tugomer does not love her suitor; he is eventually shown as a character who is morally unworthy of Zorislava, for he is the murderer of her husband. So Kmecl's parallel between Othello and Jurčič's Tugomer is only valid in one aspect, but not as regards complete personalities of both heroes. Therefore we may try to find some other, more plausible comparisons between Shakespeare's and Jurčič-(Levstik's) hero, or admit that Jurčič's hero is a one-sided portrayal of a villain. In Levstik's and in Levstik-Kreft's version of this play Tugomer is not a murderer: he is happily married to Zorislava and he meets his wife on the battlefield when he is mortally wounded. He explains to her that the slanderers did not tell her the whole truth about his life and his actions, and that he did not betray his soldiers intentionally. In these versions Tugomer - like Hamlet - hopes that his death will be a warning to the world: Tugomer dies reconciled with Zorislava in her embrace (5.3), and he asks her and his friend Bojan to tell his people about his misfortune (his tragic error) and about his political will. The parallel between the final scene in Shakespeare's Hamlet with dying Hamlet, and Horatio as the chorus, and Jurčič-Levstik's Tugomer, is obvious.

Jurčič also includes in the play a pair of young lovers (Neklon and Grozdana) whose dialogue before their separation (2.10) is a shortened pastiche of the dialogue between Romeo and Juliet after their nuptial night (Rom. 3.5). Parallels can also be drawn between the Slavic warrior Spitignev and King Richard III, both in their physical appearance (they are both hunch-backed) as well as regards their cruel nature. Spitignev - like some of Shakespeare's heroes - does not hesitate to use poison for his revenge (he poisons the girl who had refused to love him). His maxim in life is obviously the same as that of Richard III, who explains his evil nature by saying: "And therefore, since I cannot prove a lover / To entertain these fair well-spoken days, / I am determined to prove a villain / And hate the idle pleasures of these days. / Plots have I laid ..." (Richard III, 1.1.2832). Spitignev is also a person who constantly plots against others, and in this respect he is very much like Iago in Othello. But his fate is not the same: Iago is wounded (and not killed) by Othello; Spitignev commits suicide. His Frankish counterpart is Gripo, a German settler among the Slovenes, a traitor. In Levstik's text Gripo also embodies the cunningness of Iago combined with the viciousness of Edmund in King Lear.

If we compare Jurčič's original text of Tugomer with Levstik's adaptation we see that Levstik's version presents the world in new, rich artistic dimensions. Although Shakespeare's influence is seen in both plays, Levstik's character portrayal is deeper than that of Jurčič, whose prose version seems like a rough plot for a later play, which was developed into a poetic tragedy by Levstik. The characters in Tugomer are presented by Levstik in a much more sophisticated manner, as true individuals, embodying both positive and negative features. The hero, Tugomer, is not obsessed either by sensuality, or lust for power and money, he is an idealist who had made a tragic error and who eventually realizes his tragic mistake. Shakespeare's influence on Levstik's creativity of individual characters as well as his presentation of both ethnic groups, the Franks and the Slovenes, is definitely more ethically balanced than than that presented in by Jurčič in the first version of the play and therefore it achieves a higher aesthetic level. Therefore it is also closer to Shakespeare's heroes as well as to the whole concept of Shakespeare's world than the first prose version by Jurčič. Kreft's adaptation of Levstik's text includes references to Shakespeare's work which we find in Levstik's version, but with his rear- 
rangement of various passages and scenes, both Levstik's and Levstik - Kreft's version of Tugomer definitely link this play with a number of Shakespeare's histories (e.g. King Richard III, King Henry V) and with his great tragedies, for example, with Julius Caesar, Macbeth, Hamlet - and not primarily with Coriolanus. Levstik's and Levstik - Kreft's version of Tugomer show an important independence from any of the particular Shakespeare plays quoted above, especially if they are compared with Jurčič's prose version. Therefore these versions are also more dramatically persuasive and show a higher level of verisimilitude. Tugomer is the first Slovene tragedy written on the basis of classical and Renaissance type of tragedies and it therefore surpasses Linhart's Miss Jenny Love, which shows the limitations of the neo-classical domestic tragedy. Slovene dramatic art, particularly tragedy, definitely reached European standards with Levstik's Tugomer. Although quite a few parallels between Shakespeare's plays and Levstik's Tugomer can be found Shakespeare's influence was in no way damaging, but just the opposite. It shows that the Slovene dramatists of the second half of the nineteenth century did not create their plays on a direct influence of foreign masters (besides Shakespeare also Goethe and Schiller are also often mentioned as possible influences); they consciously limited themselves to myths connected with the Slavic history. Their characters are no doubt portrayals linked with some major characters in Shakespeare's plays, but they are impregnated with different emotions, moral qualities and other details which Slovene playwrights found relevant for the entire composition of their plays.

\section{IVAN CANKAR}

\section{Kralj na Betajnovi (1901; The King of Betajnova)}

At the end of the nineteenth and the beginning of the twentieth century Ivan Cankar (1876-1918) acquired one of the most important positions in Slovene literature as poet, short story writer, novelist and dramatist, essayist. He was the leading literary figure of the "Slovene modern" movement (Slovenska moderna), which is similar to the European fin de siècle movement. It is viewed as a period of transition in social and moral values and it excelled in poetry typical of the European decadence. Cankar represents this literary movement together with three other Slovene poets: Josip Murn Aleksandov, Dragotin Kette and Oton Župančič. ${ }^{18}$ But Cankar's fame is equally distributed among

\footnotetext{
${ }^{18}$ Josip Murn Aleksandrov (1879-1901) was an excellent lyrical poet who treated in his poems motifs of man's loneliness, alienation, melancholic feelings. He longed for happiness and he expressed in his poems his premonition of an early death. Both Murn and Kette lived before their death in the "cukrarna" (sugarrefinery) poor house in Ljubljana.

- Dragotin Kette (1876-1899) was also Cankar's intimate friend, who often presents in his lyrical poetry a division between sensual and spiritual love.

- Oton Župančič (1878-1949) was in his early artistic period a typical representative of the decadence in his poetry, whereas in his works written after 1900 his optimism and vitality prevail. He was the manager and the artistic director of the Slovene National Theatre (Drama) in Ljubljana and one of the best Slovene translators in the first half of the twentieth century. He translated into Slovene a number of plays written by Shakespeare and other European dramatists, in which his poetic gift sometimes even surpasses the poetic imagination of the original. He also wrote several dramatic works, among which Veronika Deseniška is his artistically most successful play (this will be discussed later).
} 
all three literary genres, and his plays represent a new quality in Slovene drama, a firm basis of all subsequent Slovene plays written in the twentieth century.

Ivan Cankar was born at Vrhnika, a small town some twenty kilometres west of Ljubljana. At the time of his birth Vrhnika belonged to the province of Carniola, then a part of the Hapsburg Empire. Cankar's father was an unsuccessful craftsman so that his mother had to provide for a large family by herself. Cankar was well aware of this fact and his mother became an idol whom he portrayed in a number of his stories and novellas. In 1896 he finished his secondary schooling in Ljubljana and went to Vienna to study engineering. But he soon realized that his vocation was to be a writer and he started to earn his bread by writing poems and short stories. At first he was impressed by the idea of the Nietzschean superman, but he soon rejected this philosophy and began to express his admiration for the Emersonian belief in an individual, in man's spiritual values, in his sense of duty to God and to one's self. In his works Cankar rejected the faults of institutional religion and the Church and his target soon became the philistine, morally corrupt individual he could see among his fellow-men. He also rebelled against Hapsburg rule, which humiliated and oppressed the non-German ethnic population of its Empire, and therefore in many of his works Cankar presents the authoritarian rule and ruthless individuals from a sharp, ironic or satirical perspective. His heroes often stand in opposition to society, but they are often not strong enough to exert a real influence on the moral norms of society and existing economic conditions. Nevertheless the final outcome of the battle between oppressive society and progressive minds of his literary individuals is sometimes seen from the optimistic point of view, although evil still wins in many of his works.

Cankar spent almost eleven years in Vienna before he returned to Ljubljana. He knew Shakespeare's poetry and wrote about it to his friend Ana Lušinova already on 2 August 1898. He states in this letter that Shakespeare's poetry is "unreachable" and that Shakespeare is his "most beloved poet" (Cankar ZD IV: 395). In the same letter he also suggests that nobody has spoken yet about his love "in such heavenly verse", and he compares his own love experience "on a soft, tender night" with Romeo's feelings when he came to woe Juliet (2.2). In 1899 Cankar was asked to revise Dragotin Šauperl's Slovene translation of Hamlet, which he gladly did. In a letter to the general manger of the Slovene National Theatre Fran Milčinski he stated that he would rather translate into Slovene three plays by Shakespeare than one act of a play written by Heinrich Kleist, which he was then also translating. ${ }^{19}$ The premiere took place on 28 Dec. 1899 at the Slovene National Theatre in Ljubljana, and in the theatre-bill only Ivan Cankar is mentioned as the translator. Dušan Moravec reports in his survey on Shakespeare's plays in Slovenia (1974: 376-77) that the play was adapted for the stage and that several scenes were omitted. However, the production was a great success and other Slovene translations of Shakespeare's plays followed soon. Cankar also translated Shakespeare's Romeo and $\underline{\text { Juliet }}$ and the translation was published in 1904, but it was only first performed by the Slovene theatre company in Trieste / Trst, in 1914.

From the point of view of this essay it is particularly relevant how Shakespeare influenced Ivan Cankar's work. Although many Slovene critics have mentioned that the

\footnotetext{
${ }^{19}$ Pisma Ivana Cankarja I (1948: 296).
} 
mouse-trap scene in Hamlet provided for Cankar the dramatic pattern for a very similar scene in his play Kralj na Betajnovi (1902), little has been said about other possible Shakespeare influences on Cankar. Among criticism related to Cankar's work in more recent Slovene studies Irena Avsenik Nabergoj also deals with possible Shakespeare influence on Cankar's poetry and prose. ${ }^{20}$ But before the presentation of this topic let me mention briefly the plot of Cankar's Kralj na Betajnovi so that parallels between Shakespeare's plays and Cankar's play may be more obvious.

In Cankar's three-act play Kralj na Betajnovi the protagonist is Jožef Kantor, a man who made his way from poverty to become the most wealthy man in a small town named Betajnova, where other people and he himself calls himself "a king". Kantor achieved this position through morally doubtful means and some people of this small town even suspect that in order to gain wealth he even murdered his own cousin. When the young bohemian student Maks Krnec rather unexpectedly returns to Betajnova from his studies abroad, he realizes that in the meantime Kantor has promised his daughter Francka, Maks's beloved, to another rich man from Betajnova, her suitor Franc Bernot: It seems at first that Maks and Francka will be nevertheless reunited, but when Kantor learns about this he strongly opposes this idea. Not long ago Kantor also forced Maks's father into bankruptcy. Maks despises Kantor and he suspects him of criminal deeds. Therefore he hypnotizes Kantor who starts to re-enact the murder of his cousin on Maks's father: Maks succeeds in this "mouse-trap scene”, Kantor grips Maks's father by the throat, but when Maks interrupts this scene and accuses Kantor of being a murderer, he denies the accusation.

Kantor realizes that it is best for him and for his plans with Francka if he could bribe Maks to leave the town. But Maks is not willing to accept Kantor's proposal and he tries to persuade both Francka and Nina, the fourteen-year-old daughter of the murdered Kantor's cousin, to leave Betajnova. However, Maks does not succeed although Francka still seems to love him. In the meantime Kantor decides to kill Maks with Bernot's rifle, which Bernot had forgotten in Kantor's pub. Immediately after the murder Kantor admits his guilt to his friends, the parish priest and to the city judge, but they pretend not to believe him and persuade him to accuse Bernot of Maks's murder, supposedly because Bernot was jealous of Maks, and as a proof Bernot's rifle is used. The Priest and the Judge represent "the pillars of society" in Betajnova and for them Kantor is too rich a prey to be found guilty. Instead, Bernot is taken to prison. Francka and her naive and terrified mother stay with Kantor, who sends Nina to the monastery because she knows too much (she had heard the shrieks of her dying father). Kantor remains "a king in Betajnova", and he tries to exculpate himself from his crimes by saying that "in order to achieve something for himself, for his parish, for his nation, one cannot be merciful,

\footnotetext{
${ }^{20}$ Irena Avsenik Nabergoj, Ljubezen in krivda Ivana Cankarja (Ljubljana: MK, 2005: 48, 183, 221, 245 , $250,253,298,316,521)$. She finds Cankar's source of inspiration for his short stories in Hamlet, Macbeth, King Richard II, and for Cankar's poems in several Shakespeare's sonnets. In her article published in the review Jezik in slovstvo 53.2 (Mar.- April) 2008: 33-47, she compares violence in Cankar's Kralj na Betajnovi with violence in Hamlet. This is also the main theme discusssed in I. Nabergoj's reader for the final exam in Slovene secondary schools (Dramatika na maturi. Nova Gorica: Založba Univerza v Novi Gorici, 2008: 37-59). - Let me mention here that Cankar was pleased with his work as a translator, which he mentions also in several other letters he wrote e.g. to his brother Karl, to his friend Oton Župančič etc. (Moravec 1974: 397).
} 
but in order to reach the throne one must walk in blood up to his knees." (Cankar ZD $I V$ : 66). Parallels between Shakespeare's Hamlet and Cankar's Kralj na Betajnovi are especially noticeable in the first act of Cankar's play, particularly in the mouse-trap scene and partly also in some minor features in Acts 2 and 3.

The first literary historian to mention the parallels between Hamlet and Cankar's play was the Italian scholar Bartolomeo Calvi, who also wrote in 1929 the introduction to the Italian translation of Cankar's play. ${ }^{21}$ His main points regarding the connection between Shakespeare and Cankar are the following: Calvi accepts the view that Cankar did not wish to celebrate in the play the Nietzschean superman, personified by the protagonist, wealthy and powerful Kantor. This topic has been also treated by several Slovene critics (e.g. France Koblar, Matevž Kos etc.), ${ }^{22}$ and their solutions regarding Nietzsche's influence differ. Calvi questions Maks's use of hypnosis wondering why Maks did not use the knowledge he gained about Kantor later, as his evidence to prove Kantor's crime. According to Calvi Maks "forgets" his father's disappropriation, which he could also use against Kantor. Calvi finds a parallel between Shakespeare's Gertrude in Hamlet and Cankar's presentation of good-hearted and simple-minded Ana, Kantor's wife. These comparisons are acceptable, but Calvi's parallel between Maks's father and Horatio (1929/1930:113) is not very plausible. Horatio's relationship with Hamlet is much deeper, it is more strongly present than Maks's relationship with his father and it is therefore also much more dramatically important. Horatio is dealt with in Hamlet as the hero's trustworthy friend, a real confidant, whereas Maks's father Krnec plays in Cankar's The Kings of Betajnova a minor role. Finally, Calvi' aesthetic evaluation of Cankar's play is relatively high although he does not place it as high as Shakespeare's Hamlet or Henrik Ibsen's Ghosts (a much more appropriate thematic comparison would be with Ibsen's Pillars of Society, 1877). Because of Cankar's use of the mouse-trap scene, Calvi mentions Cankar's play as a kind of predecessor of Luigi Pirandello's intellectual approach to the presentation of life in art, and he mentions Pirandello's play Six Characters in Search of an Author (1921). ${ }^{23}$ This comparison between Cankar's and Pirandello's play - as flattering as Calvi may have meant it to be - is not very persuasive either because the two plays differ in their themes, plots and structures and the use of "the play within a play" is hardly sufficient grounds for such a comparison. However, in spite of some objections to Calvi's interpretation of Cankar's play, we should mention that he was the first critic to observe possible parallels between Shakespeare's Hamlet and Cankar's play.

France Koblar, one of the first Slovene literary critics especially interested in drama, enumerates in his survey of Slovene drama (1973) some other parallels between Hamlet and Cankar's play. Both Hamlet and Maks were studying abroad before they returned home after some crucial events had transpired there. Both major female figures, Ophelia and Francka, were supposed to marry their beloved (Hamlet / Maks),

${ }^{21}$ Bartolomeo Calvi, Il re di Betainova (Torino: Societa Editrice Internationale, 1929). His essay appeared also in Slovene translation in the review Modra ptica (1, 1929/30: 444-47, 67-70, 88-92, 113-117).

${ }^{22}$ Several critics, e.g. Dušan Moravec (1969: 294), France Koblar (1973: 54), find in Cankar's play a combination of Shakespeare's revenge motif and the Nietzschean philosophy of the superman. On the other hand, Matevž Kos states that Kantor is more like a caricature than a candidate for the role of Nietzschean superman (Matevž Kos, Poskusi z Nietzschejem. Ljubljana: SM, 2003: 175).

${ }^{23}$ Calvi 1928: 88. 
but in both cases their fathers intervened so that the marriage was prevented. Koblar also concludes that in both plays evil wins (1973: 53). This point is only "technically" correct, because Hamlet dies prophesying "the election lights / On Fortinbras" (5.2.5354) and he justly believes that law and order will be restored in Denmark, whereas in Cankar's play evil definitely wins in Betajnova. Another historian of Slovene drama, Dušan Moravec, defines in his notes to Cankar's play Maks as "a dreamer", "a genius of a vagabond", who is "honest and clever" (ZD IV: 294). These attributes may well refer to Hamlet too (with the exception of being a vagabond). Moravec also finds the moral corruption of the Judge in Cankar's play as too exaggerated (Cankar ZD IV: 294); we may also agree with this view because both characters, the Priest and the Judge are in Cankar's play drawn more like caricatures and not like other realistic portrayals of people in Betajnova.

Among more recent interpreters of Cankar's play Janko Kos appropriately points out that Maks only wishes to rouse Kantor's conscience, i.e. Maks's vengeance is only ethical, whereas Hamlet's revenge is also physical. Hamlet's doubts about his "moral duty" to avenge the death of his father are not present in Maks's personality, which is "autonomous and ideal" (Kos 2001: 263). Thus Cankar "departs" from Shakespeare: Claudius is guilty on several levels (emotional, social, religious, moral), whereas Kantor's guilt is only the product of his quest for power.

In her study on Cankar the Slovene critic Irena Avsenik Nabergoj also mentions Cankar's use of "the mouse-trap scene" in his play Kralj na Betajnovi. Besides, she makes a persuasive suggestion about Cankar's female roles: the author always searches for the image of a perfect woman, but he must eventually recognize that his "idol" is just an ordinary human being (2005: 698), and Cankar's Francka definitely does not surpass such a character (the same is true of Ophelia). Nabergoj's point that the "conflict" between Maks and Bernot can be compared with that between Hamlet and Laertes is partly valid, because the rivalry between these male characters is in Cankar's play only briefly indicated. The relationship between Hamlet and Laertes is much more complex and more deeply developed whereas Bernot is (if compared with Laertes) a rather flat character. Nabergoj's assertion that Shakespeare included in his tragedies also comic scenes is correct, but it would be hard to find comic elements which are "depicted concurrently" in Cankar's play (2005: 219), as she suggests, and which would relate to Shakespeare's style.

However, in addition to the above mentioned parallels between Shakespeare's Hamlet and Cankar's Kralj na Betajnovi we can also notice some other examples, which have not been mentioned yet. Kantor's antagonist, Maks Krnec, tells Francka that he was not badly hurt when her father caused the bankruptcy of his father's property; but he states that he is angry because Kantor uses his power to tread upon human beings (10). Maks adds that the whole surrounding of Betajnova smells of "bad dreams" (12); this image, which is olfactory, is similar to the conclusion made by Marcelus, namely when he says, "Something is rotten in the state of Denmark" (Hamlet 1.4.90). Both images denote the social, the ethical as well as the mental situation of these settings. Although Maks does not see "the ghost of Kantor's cousin" who would tell him that he was murdered, he says that he sees this truth "written on people's faces", or, as his father suggests, he must have heard the rumour, which is spread in Betajnova "by women" (29), 
this is that Kantor had possibly murdered his cousin. Although Maks is certain that he is right in his suspicion Maks "cannot strike back". He blames his "impotence" on his father, who had created him "so small, such a weakling" (30). We may hear in Maks's complaint Hamlet's words: "O, that this too too sullied flesh would melt ...", in the monologue in which Hamlet also states that he is not "like Hercules" (1.2.129-153), and that "so poor a man as Hamlet is" feels morally obliged to set things right (1.5.184-89). When Maks meditates about the situation in Betajnova he tells Francka that he does not feel well; he anticipates that something bad, something evil is going to happen (28-9). It is possible that Maks's thoughts refer to his intention to commit suicide, the thought which also crosses Hamlet's mind on the above mentioned occasion (1.2.131-32). Maks tells Francka that his life has ended and that the dead have no right for love (42), but Francka does not understand him and at that moment she still hopes that she would leave Betajnova together with Maks and start a new life in town. But both young lovers, Ophelia and Francka, ultimately function in the same way, they both obey their father's will and are at least partly guilty for the deaths of their beloved.

After Kantor re-enacts the murder of his cousin and Maks rouses his conscience, Kantor knows that his "dreams" were real and that his sins cannot be forgiven ("erased", 32). Kantor's speech is a brief version of the interior monologue spoken by Claudius in Hamlet (3.3.35-72) in which Claudius admits that God cannot forgive him, because he is not willing to part with his gain, i.e. to admit his guilt, to separate from Gertrude and to give up his power. Just as Claudius is sure that he wants to get rid of Hamlet, Kantor's reply to Francka is that he is going to be "healthy and well when Maks -". Kantor does not finish the sentence, but, judging by his question, which follows, "Whose rifle is this?" (34), we can surmise that his full answer would be: "- when Maks is dead". Claudius decides that he must get rid of Hamlet and he sends him to England, and when Kantor realizes that Maks does not wish to leave Betajnova of his own free will, or to accept bribes, he decides to get rid of Maks and to kill him at the first opportunity.

Even though Kantor is mainly modelled on the image of Claudius we can also discover some links between Kantor's character and that of Macbeth. Although Kantor - like Macbeth - knows that his "False face must hide what the false heart doth know" (Macbeth 1.7.27), he has his weak moments, too. For example, Kantor is not as "strong" and "straightforward" in his evil doings as Macbeth, and besides, his criminal nature is almost discovered by the priest and the judge after Maks's murder. If "the pillars of society" in Betajnova had not been so morally corrupt Kantor would have been imprisoned and convicted. He is also a living proof of Macbeth's statement that "blood will have blood" and that he is "in blood stepp'd" (3.4.122; 126-27). Although Maks tries to remind Kantor that his "kingdom is stolen" and that his "slaves" (Kantor's workers whom Maks had tried to show reality, and who will, as Maks believes, one day raise against Kantor), "the king" is not afraid of his threat, he behaves like Macbeth before the final duel with Macduff; he is ready to fight and even to die. On the other hand Cankar allows evil to win and Kantor promises to his young sons that he will raise them in such a way that they will become like him.

Maks neither has the energy nor the power to end Kantor's rule. He admits that he felt like an alien when he lived abroad, but he is now an alien also in his native land. 
On the other hand Kantor is willing to sacrifice everything for his "kingdom", even his daughter's love, and although people in Betajnova, including the members of Kantor's family, know what kind of a man he is and are terrified of him, when he proposes the toast, all the inhabitants of Betajnova drink to his health. The untying of the knot in Cankar's play Kralj na Betajnovi is completely different from Shakespeare's Hamlet: Cankar's characters annihilate any possibility of catharsis and turn the events in the play into a grotesque version of reality. In Hamlet the festivity takes place at the beginning of the play, when the crime Claudius had committed is not yet known, in Cankar's play the rejoicing takes place after Kantor had murdered his cousin and Maks. In Cankar's play the tragic events culminate in "a happy ending", because the society is so completely corrupted that the final "merry-go-round" fills us with terror.

By the beginning of the twentieth century - when Cankar wrote this play - three hundred years had passed since Shakespeare's Hamlet was written. Although Cankar used in Kralj na Betajnovi several motifs, incidents and characters which resemble Shakespeare's Hamlet and to some extent also Macbeth, Cankar's vision of the world, his view of ethical norms, and of man's moral principles is totally different from Shakespeare's norms, it is much more bleak and it does not offer any positive hope for man's future. Does this mean that in Cankar's view man's behaviour and his ethical standards have been so much degraded during the past few hundred years? Can we assume that Kantor's immoral, liberal, capitalist, economic, political and social power completely dominate the modern world?

\section{IVAN CANKAR}

\section{Pohujšanje v dolini Šentflorjanski (1907, Scandal in the Valley of St. Florian)}

In Ivan Cankar's later work parallels between Shakespeare's plays and his plays are not as numerous as in Kralj na Betajnovi. Cankar's farce Pohujšanje v dolini Šentflorjanski was published in October 1907. Its premiere took place two months later, on 21 December 1907, at the Slovene National Theatre in Ljubljana. ${ }^{24}$ It is worth remembering in this connection that Cankar had translated Hamlet into Slovene in 1899. Even before this date, already in 1896, he had mentioned Romeo and Juliet in the first poem belonging to the cycle "Helena", and also in one of his letters in which he compared their love with his own feelings for a young lady. ${ }^{25}$ His second translation of Shakespeare's plays was this play, Romeo and Juliet, which was published in Slovene in 1904 (but staged only in 1914). These facts are relevant for the understanding of allusions made by Cankar in this poetic play Pohujšanje v dolini Šentflorjanski. Its main themes are the hypocrisy of the small-town folk in his native country and, on a symbolic level, the ignorance of the public to the artist's work.

The plot of this play deals with the unexpected arrival of an artist and a vagabond, Peter, to St. Florian Valley. He is accompanied by a beautiful young woman,

\footnotetext{
${ }^{24}$ The play was translated into English by Anthony J. Klančar under the title Scandal in the Valley of St. Florian and performed at the "Slovenski narodni dom" in Cleveland on 18 March 1934.

${ }^{25}$ Cankar ZD IV (1968): 395.
} 
Jacinta, and their servant, called Konkordat, who is actually the Devil himself. Peter had promised all the souls of this valley to Konkordat for services rendered. At night Peter visits the Mayor and tells him that he is the foundling, his bastard son, whom the villagers had forced to leave the valley some twenty-five years before. As compensation Peter now claims from the Mayor one hundred forints, and later he claims the same amount from each villager who comes to see him and Jacinta in a shabby house at the end of the village where they live. He accuses them - one after the other - of being his unacknowledged father. The men obviously feel guilty of their immorality and they are all asked to kiss the leg of beautiful Jacinta. Cankar shows how their moral norms have not changed because they gladly do what Peter commands them to perform. The Devil thus discovers that all the villagers (and their wives) are sinners and hypocrites and that Peter had played a trick on him and on the villagers. Nevertheless they are so overwhelmed by Peter and Jacinta that they provide a beautiful castle for them. Peter arranges a festivity there for all the villagers and he asks Jacinta to dance for them. In the meantime a poor, young boy appears at the castle, and he tells Peter that he is the real foundling and that Peter is looked for by the police; Peter decides to leave the castle together with Jacinta in a hurry. He promises her that their voyage will be "full of joy and pleasure" and they will thus also deceive the law. Peter advises the young man to be harsh with the villagers, who wish to forget the whole episode as quickly as possible and begin to sing a religious hymn about St. Aloysius, the patron of young, innocent people. They pretend that nothing had happened and that they are as virtuous as ever. However, Peter and Jacinta have definitely discovered their immorality, their hypocritical image.

In one of his letters Cankar demanded from the theatre manager that "Jacinta should be very beautiful [as] otherwise the play was not to be staged at all" (Cankar ZD 1968: 351). Janko Kos suggests in his comparative history of Slovene literature that Cankar may have had in mind Jacinta's performance of Salomé's dance of the seven veils in Oscar Wilde's play bearing the same title. Several Slovene literary historians (e.g. F. Koblar, D. Moravec, J. Kos etc.) also briefly mention in their works that Cankar admired the poetic beauty of Shakespeare's Romeo and Juliet. Shakespeare's influence is particularly noticeable in Act 2, Scene 1 of Pohujšanje v dolini Šentflorjanski, which can be compared with the initial dialogue between Romeo and Juliet (2. 2). Cankar uses here endecasyllabo, a typically Petrarchan form of verse, which is also typical of Slovene love poetry. Besides, a number of parallels can be found between both plays, e.g. Jacinta tells Peter that the candle light is not necessary, because there is moonlight and "the light" in their hearts; they feel to be in heaven although they have not emptied yet their chalice of love; Jacinta hopes to receive gifts of "velvet, silk and brocade ... together with gold and precious stones", etc. These epithets and images are very similar to those mentioned in Romeo and Juliet and in some of Shakespeare's sonnets. Both Juliet and Jacinta ask their lovers whether they still love them, when they have to leave their happy haven (Romeo and Juliet 2.2.90; Pohujšanje v dolini Šentflorjanski 2.1, 88). They both complain that the night was too short, and both men, Romeo and Peter, are aware that they are obliged to leave: Romeo must leave Verona if he does not wish to disobey the order of the Prince and to stay alive, and Peter knows that the police are after him and that therefore they should immediately leave St. Florian's valley. $\underline{\text { Cankar's }}$ 
Peter is a more complex character than Romeo: he is not only a lover, but he is also an artist, or at least he used to be until he lost all his "hopes, his longing and his inspiration". Therefore his call to go on the road again may be an unspoken promise that his artistic creation will be revived again.

Cankar had explained on several occasions that he would not have written this satire had he not loved his country so much (ZD 1968: 340-346). He also points out that Jacinta's role was to show "the artist's more beautiful and higher level of life, the symbol of his art" (ibid.), which Cankar had felt that it had not been appreciated enough. Konkordat, the Devil, offers Peter and Jacinta material riches, which are as dubious as the supposedly "innocent souls" of the villagers. Konkordat's role of Mephistopheles is to ruin the souls of the inhabitants of St. Florian valley, but Cankar turns his attempt into a satiric picture of contemporary society, which is already so morally corrupt that the Devil is needed no longer to do his job. ${ }^{26}$ In this passage we may discern several elements of the syntactical pattern used in Hamlet's monologue before his final duel with Laertes ("If it be now, 'tis not to come - if it be not to come", Hamlet 5.2.216-220). Cankar knew it well because he translated Hamlet; he used it here to create the uncertainty about the success of Konkordat's mission. This compound sentence based on conditional clauses is rhetorically very noticeable and effective in both plays.

Cankar's play also includes a number of symbolic references: Peter represents an artist, who is in love with life and the arts; Jacinta stands for the arts; the "villagers", represent the public which does not understand and does not appreciate the artist's vision to create beauty. Here we can see a posssible comparison with Shakespeare's symbolism in The Tempest: Prospero and Peter are artists, "magicians", Miranda and Jacinta are their art, Caliban is Konkordat, the sailors are the inhabitants of the St. Florian Valley, uncultured, rough companions, the public. There is no direct evidence that Cankar knew The Tempest and therefore these parallels regarding the symbolism in both plays may simply reflect similar perception of life and the arts of both playwrights. However, the other examples cited above are definitely the result of Cankar's first-hand knowledge of Shakespeare's Hamlet and Romeo and Juliet.

\section{IVAN CANKAR}

\section{Lepa Vida (1911, Beautiful Vida)}

Hrepenje (w. in 1906; Yearnings, a fragment, first publ. in 1968)

Hamlet iz cukrarne (w. in 1909; Hamlet from the 'Sugar-refinery' Poor-house, publ. in 1969)

\footnotetext{
${ }^{26}$ Cankar degraded the role of Mephistopheles in comparison with his role either in the medieval legend or as shown by Christopher Marlowe in his play Dr. Faustus or by Goethe in Faust.
} 


\section{IVAN CANKAR and MILE KORUN}

Lepa Vida (2001, Hrepenenje - Hamlet iz Cukrarne. - (Beautiful Vida, Yearnings, Hamlet from the 'Sugar-refinery' Poor-house. Scenes were selected and arranged by Mile Korun)

Cankar's play about a beautiful young girl, called Vida, is the result of his previously written dramatic fragments (Yearnings, Hamlet from the 'Sugar-refinery' Poorhouse) and his play, Lepa Vida (Beautiful Vida). He treats in them the theme of man's longing (for the meaning of life, for beauty, happiness, death etc.). The scene of the first and the third act of Lepa Vida is set at the poor-house in Ljubljana, and the second act takes place at Lake Bled. In the poor-house two of Cankar's best friends, the poets Josip Murn and Dragotin Kette, lived and died so that the play although based on a myth also has the author's personal background. ${ }^{27}$ Cankar's play Lepa Vida was first produced on 27 January 1912 at the Slovene National Theatre in Ljubljana. It is a poetic play in which metaphoric language prevails and therefore it is not surprising that it is one of the least frequently performed plays written by Cankar. Almost ninety years after its premiere a new version was prepared by Mile Korun, who is one of the leading Slovene theatre directors of the second half of the twentieth century ${ }^{28}$ His version of Lepa Vida is a compilation of all three texts, and it is structured in such a way that there is a clear distinction between the reality and the dream-scenes in which Cankar's characters live.

The motif about beautiful Vida has appeared in Slovene literature as an archetypal pattern in several variants, and from the beginning of the nineteenth century onward it has inspired some fifty Slovene authors who have dealt with it in their literary works (in poems, prose works and in plays).$^{29}$ Slovene literary historian Anton Slodnjak (1968:14) believed that this motif was even related to motifs treated in Aeschylus's Oresteia and Shakespeare's Hamlet. The central figure of this myth is a young woman (most frequently a mother), who has a small sick child and who is married to an old husband. She longs for a new, a different, more beautiful life. In several variants of this motif the

${ }^{27}$ Among Cankar's dramatic fragments there is also a short episode called "Niobe". Cankar first mentioned it immediately after he had translated Hamlet. This may indicate that Shakespeare's mentioning of Niobe in Hamlet (1.2.149) was the immediate reason why Cankar chose this title for a possible play. Like Niobe, who is in Greek mythology the daughter of Tantalus and who has lost her children, Cankar's portrait of a Mother (as a character) in this scene is found in the same situation. But the theme of this episode is only connected with Lepa Vida through its motif of man's departure from home and consequently with mother's sorrow, which is also present in Lepa Vida. The plot of Cankar's unfinished play is similar to a short play Riders to the Sea, written by the Irish playwright John Millington Synge (1871-1909). Synge's play was first performed at the Abbey Theatre in Dublin in 1904. Towards the end of the nineteenth century many Slovenes (like many Irish people) left their homes and went to America which was probably also Cankar's main reason for his interest in this theme.

${ }^{28}$ Cankar's complete text of Lepa Vida was published in the collected edition of his work (ZD V, 1969: 67-110), where also both fragments were printed ("Hrepenenje", $Z D I V, 1968$ : 125-138, and "Hamlet iz cukrarne", $Z D V, 1969:$ 118-131). Korun's version was printed in the theatre-bill of Mestno gledališče ljubljansko (The Municipal Theatre of Ljubljana), 4 (2001-2002), published at the premiere on 15. Dec. 2001: 1-48. Although Cankar changed names of several characters in his fragments and in his play, they are easily recognizable because of their noticeable personal features.

${ }^{29}$ Jože Pogačnik enumerates different versions of this myth which have been published by 1988 (Pogačnik 1988: 8-9) and Denis Poniž mentions also other, later versions (Poniž 2006). 
story is based on the life of a beautiful young woman, who is washing the baby's diapers on the shore of the Adriatic Sea. She is enticed (in some versions forced) by a black sailor to board the ship..$^{30}$ Then she is taken to Spain to serve there as a wet nurse to the Queen's child. What at first seems to Vida as a kind of adventure (even if in the eyes of local people she is sometimes regarded as a morally degraded person) turns out to be a sorrowful experience, which is presented differently by various authors. According to one version Vida is employed at the Spanish court as a wet nurse and she lives there a happy life; according to another version she is not happy in the foreign land and she misses there her child and her country. The final part of some of these ballads also has two contrasting endings: according to one version Vida returns to her native land, or, according to another, she remains abroad. Boris Paternu suggests that Cankar was most probably inspired to write his play by a ballad written on this theme of a folk song by the Slovene poet France Prešeren. In his poem "Od lepe Vide" (About the beautiful Vida) the black sailor was asked by the Queen of Spain to bring Vida to the Spanish court. ${ }^{31}$ But once Vida is on the open sea she regrets her decision and when she serves at the Court she is not happy although the Queen is nice to her; she looks through the window and cries every day when she thinks about her sick child and her old husband whom she had deserted and thus betrayed. The motif for her "escape", which is according to views expressed by Boris Paternu, is not so much erotic and social as it is in some other versions of this ballad. ${ }^{32}$

In Cankar's version of this archetypal motif the figure of the beautiful Vida is used both as a dramatic character as well as a symbol representing man's desire for something unattainable, something what may often seem to be within man's reach but what always finally escapes him. ${ }^{33}$ The setting of the play in Ljubljana is an old five-storey building, a sugar refinery which was built in 1830 on the outskirts of the city ("cukrarna" is a Slovene slang word derived from the German word "Zucker", i.e. "sugar"). The building was later used as a barracks and then, at the end of the nineteenth century, it was turned into a poor-house in which also many students and bohemian artists lived. This five-storey building (which still exists but which is now empty) has dark corridors, the walls are covered with moss, and it is generally in a very poor condition. Two of Cankar's best friends, Slovene poets Dragotin Kette and Josip Murn, lived there for a number of years and also died there at the prime of their lives (see note 17). Cankar refers to this building as "a huge morgue". Its inhabitants wish to leave the building but they do not have enough will and energy to do so. The situation in which these lodgers are is hopeless and when they see a beautiful young girl, Vida, who also lives in this poor-house with her mother, they are extremely happy. The central theme of the play is the expectation of a group of lodgers hoping that Vida, who has gone out one evening

\footnotetext{
${ }^{30}$ In the nineteenth century the region west of Trieste / Trst was still settled mainly by Slovenes. In histories of Slovene folklore it is mentioned that Vida came from the hinterland of Trieste / Trst, i.e. between Nabrežina (Ital. "Aurisina") and Devin ("Duino"). The region then belonged to the Hapsburg Empire and since 1919 it belongs to Italy.

${ }^{31}$ France Prešeren ZD 2 (1966: 131-34).

${ }^{32}$ Boris Paternu I (1976): 141-45.

${ }^{33}$ The symbolism of "beautiful Vida" has been interpreted in many diverse, even paradoxical ways (e. g. as the symbol of love/death, beauty, art, new life, nation's collective memory etc.). See: Pogačnik (1988) and Poniž (2006).
} 
with a rich suitor, is going to come back to the poor-house, to bring to their life again "new light", new hope. But only a fifteen year old student really believes that Vida is going to come back and he hopes that one day he and Vida will leave the poor-house together and start a new life in a nicer world.

Many Slovene literary historians and critics have written interpretations on Lepa $V i d a$ and they interpret the play from various perspectives, but with very few exceptions they do not deal at all with possible influences Shakespeare had on Ivan Cankar when he was writing this play, ${ }^{34}$ with parallels between Shakespeare's plays and Cankar's play. In his notes to the play Dušan Moravec points out that this connection can already be seen in the title of one of the earlier fragments, which bears the title of Hamlet. Cankar's hero, Vehovec, is such an indecisive person like Hamlet, who wavers between life as "the prison" and his desire for new life. The very name, "Vehovec", is in Slovene a variant of "vehavec", which is a synonym for a hesitant, indecisive person (SSKJ 1994: 1498). When in the fragment Hamlet from the Sugar-refinery Vehovec admits to Schweiger that now he has no moral restraint as regards his dealing with women (Vida is meant here) the latter tries to console Vehovec by telling him that other men have also cheated "girls" but that they continued their lives as if nothing had happened (Cankar ZD V 1969: 124). Likewise, Hamlet does not wish to stop his activities in connection with his father's death, even if he hurts Ophelia ("Nymph, in thy orisons / Be all my sins remembered." 3.1.89-90); or, when he denies he had given her presents and Ophelia claims that he had given her "remembrances of yours" (ibid. 3.1.93) and that he had spoken "sweet" words to her. Hamlet - even though he may be touched by Ophelia's words - wishes to continue his search for the murderer and responds to her plea with a grotesque laughter. Neither "hero" is willing to admit to the women to whom they made certain promises that this was so. But in some crucial moments, when death is near, they could easily use the rhetoric Hamlet uses in his dispute with Laertes at Ophelia's grave, or when Hamlet (or Vehovec) was asked, "What wilt thou do for her?" they would both proclaim their love by saying: "I'll do't." $(5.1 .265 ; 271)$

Cankar's spiritual symbolism offers many possibilities for diverse readings, and the waiting of his characters at the poor-house is very much like waiting of Didi and Gogo in Samuel Beckett's play Waiting for Godot (1954), or even like passive characters in Chekhov's plays. One of the main characters in Cankar's play, the poet Štefan Poljanec, says to another lodger of the poor-house, a young student Damjan: "Don't worry, Damjan, don't worry! We shall wait until she comes!" Another lodger, Peter Novljan, tries to console them all: "We shall wait until the end" (ZD IV, 1968: 126). Waiting is the essence of the lives of these men, although some of them "had a glimpse" that Vida may never return and that they will remain prisoners of "this morgue" $(Z D V, 1969$ : 129). They call the sugar-refinery "the prison", because it is like a limbo from which these men cannot escape. Their situation is similar to Hamlet's experience of Elsinore, after the death of his father, when he tells his former fellow-students Rosencrantz and Guildenstern that "Denmark's a prison" (2.2.245). In Cankar's play the lodgers feel

\footnotetext{
${ }^{34}$ Among well-known Slovene literary historians who have written books and essays on Cankar are Ivan Grafenauer, Lojz Kraigher, Božo Vodušek, Josip Vidmar, France Koblar, Dušan Pirjevec, France Bernik, Taras Kermauner, Janko Kos, Jože Pogačnik, Denis Poniž etc. Among authors who have discussed Cankar's debt to Shakespeare are Dušan Moravec (1964) and Irena Avsenik Nabergoj (2005).
} 
pity for themselves, and they know that they cannot change their lives, that they will not leave the poor-house and that they have become its victims. One of the lodgers tells his companions that when Vida comes back they will hear three knocks on the wall. But they are also aware that according to the folk legends the knocks may also indicate "the coming of death". Such a knock was apparently heard by one of the lodgers when Cankar's friend Murn had died in the poor-house. The knock is an element of superstition, which - according to ancient myths - announces the soul's departure from this world. Shakespeare uses it in Macbeth when the knock is heard by the Porter (2.3) and then it is discovered that King Duncan and his two soldiers were killed during the night. In "A Game of Chess", in the second canto of T. S. Eliot's poem The Waste Land, the symbolic meaning of the knock is the bartender's knock at closing time in British pubs, which is also thematically closely connected with different kinds of death mentioned in Eliot's poem.

Among references to Shakespeare's plays, which are noticeable in Lepa Vida and which have not been discussed yet, is also a short passage related to Hamlet's meditation about man's qualities. Hamlet delivers this speech after he had realized that Rosencrantz and Guildenstern are not his true friends but that they were asked to come to Elsinore by the King and the Queen to inform them about his health, or rather about his "real plans". Hamlet says: "What a piece of work is a man, how noble in reason, how infinite in faculties, in form and moving, how express and admirable in action, how like an angel in apprehension, how like a god"; but then he expresses his disappointment with man's nature with his remark, "... and yet to me, what is this quintessence of dust? man delights not me, no, nor woman neither...” (2.2.307-313). In Lepa Vida Cankar's drunk, sensual, nihilistic Mrva makes the following remark about man: "O, friends, what a coward is man! And what a liar he is..." (Cankar - Korun 2001-2002: 83). Shakespeare's hero still sees both extremes of man's nature, whereas Cankar's comment on man's nature is only negative.

Cankar's characters are not always certain whether they live "real life" or "the life of illusion". They see their life as "a stupid and funny comedy" (ibid. 82), and they are aware that there is no meaning in their waiting, which is only their waiting for death. This reference to the stupidity, and the absurdity of life reminds us of a short monologue spoken by Macbeth after his wife had committed suicide. He says: “... all our yesterdays have lighted fools / The way to dusty death", and that life is like "a tale / Told by an idiot, full of sound and fury, / Signifying nothing" (5.5.22-28). Such a nihilistic view, which presents man's existence as meaningless, can also be found in diverse statements made by Cankar's characters, although they still occasionally foster hopes about a different kind of life, on that they would like to live. Only Vida's mother stoically accepts the death of one of the lodgers, the poet Poljanec, and she thinks that he has taken "the most beautiful road" (ibid. 100). This is also the way with which Hamlet accepts his death. The virtual world in which Cankar's characters live cannot be bridged with their desires, because the only reality which awaits them is death. Like Hamlet at the beginning of the play, these men are also afraid to act, but they are also afraid of dying, they are cowards who are afraid to commit suicide. Hamlet also expresses his fear of death (1.2.129-132), and so does Mrva, one of the characters who is a person more "down to earth" (Cankar - Korun 2001-2002: 82). 
Hamlet's doubt and his indecisiveness are also present in Cankar's characters, but they never reach that stage in Hamlet's life when he takes action into his hands regardless how morally dubious his actions may be (e.g. Hamlet's change begins with his killing of Polonius). Therefore Cankar's characters are doomed to failure, their dreams cannot come true. Cankar's play Lepa Vida offers a number of images and syntactical patterns which link it with Shakespeare's metaphorical world. For example, before Vida's return to the poor-house Poljanec compares man's aspirations with a leaf, which was blown by the wind into "a brook under the willow tree" and which the wind aimlessly takes from one side to another side of the pool, but which represents only "man's longing after a long, long sleep" (Cankar - Korun 2001-2002: 78). The scene and the metaphor of this passage remind us of Ophelia's death: "There is a willow grows askant the brook, / That shows his hoar leaves in the glassy stream" (Hamlet 4.7.165-166). Poljanec and his companion Mrva, who are both fatally ill, also mention in the play several times that "the light ... will be extinguished", thus referring also to the coming of death. Shakespeare uses this image in Othello (5.2.7), when the hero is about to smother his wife. The image of "a brief candle" symbolizes the brevity of man's life, and Macbeth also refers to it before his death. (5.5.23)

When Vida returns to the poor-house after she had spent the evening with a rich proprietor, she admits to the lodgers that she has betrayed them. Cankar indicates her "fall" with the description of her new, glittering and at the same time cheap dress, its low neckline, and with flowers in Vida's hair. When Vida sees the scornful faces of her companions at the poor-house she realizes what she has done to them, just as Gertrude is forced by Hamlet to see the culpability in her relationship with Cludius (3.4). Vida, who is admired by this group of men in the poor-house as "a princess" or like "a queen", becomes - due to her escapade - "the most seeming virtuous queen" (1.5.46), as the Ghost of Hamlet's father refers to Gertrude, who had betrayed him with his brother Claudius. In Lepa Vida only young, inexperienced Dioniz, remains steadfastly on Vida's side. Vida tells the lodgers that "the other world, the paradise", is not her real home but that her home is "the way". She seems to express here the author's voice, his persuasion that the final aim of man's life is not to reach his goal, but to continue his travels along the road of life.

One of the obstacles which Cankar's characters face in their travelling through life is "the language" they use. So, for example, one of the characters, Milena, realizes that she had betrayed her friend Franc when she persuaded him to see things, which were not real, and when she made him say lies. Cankar uses such ironic remarks about the use of language which remind us of the comment used by Hamlet when he makes fun of Polonius and his persuasion that he can discover Hamlet's thoughts. When Polonius asks Hamlet: "What do you read, my lord?", he gets an enigmatic answer, "Words, words, words" (2.2.191-192). Hamlet makes Polonius even a bigger fool when he tricks him to admit that the shape of a cloud is "almost in the shape of a camel", that it is "like a weasel", "Or, like a whale." (3.2.379-384). Milena admits that during her "enchantment" with Franc, they had made each other say things, which were only the product of their imagination (e.g. "the fool moon" became "the sun", "the barn" was described as "a castle" etc. Cankar - Korun 2001: 31); people see what they wish to see. One of the main problems of Cankar's characters is that they cannot distinguish 
between the reality and their dreams. Milena believes that her Franc, who had spent the evening with Vida, only dreamt about Vida, but Franc, on the other hand, admits that he and Milena have cheated each other. Cankar's characters in Lepa Vida see themselves as prisoners, but even if they accept their own dreams as the reality, they eventually realize that they have only cheated themselves. Poljanec, the poet, describes a young man's vision of life as "a miraculous flower", which leads him through the difficulties of life to his dreams (Cankar - Korun 2001-2002: 95). Cankar's characters mostly live in a virtual world, from which they cannot escape, just as Macbeth and Lady Macbeth have no possibility to change their lives after they had decided to obtain their goal by killing. Cankar's characters are also enchanted by the prospects of death, they long after heavenly nirvana. The director of the new version of the play, Mile Korun, had even intended some realistic scenes (e.g. Nina's dialogue with Dolinar) to be shown as a pantomime (ibid. 70) what would definitely remind the spectators of "the dumb show" in Hamlet (3.2), in which the King's poisoning is shown. The duality of characters living either in reality or in dreams was polemically introduced by Korun through the juxtaposition of characters, their feelings, their thoughts. Although Shakespeare's influence upon Cankar is in this play less direct than in the previous two plays discussed in my article, the very features of character of Cankar's irresolute, hesitant dreamers, as well as some selected thematic parallels mentioned above, show that Cankar was in this play still inspired by the Bard's artistic genius, particularly by Shakespeare's Hamlet, which Cankar translated into Slovene in 1899.

\section{OTON ŽUPANČIČ: VERONIKA DESENIŠKA (VERONIKA OF DESENICE)}

One of the most important Slovene lyrical poets in the first half of the twentieth century was Oton Župančič (1878-1949). Like many other Slovene intellectuals he also studied in Vienna and then he also stayed for a short period of time in Paris. After his return to Ljubljana in 1910 for the rest of his life he remained mainly connected with the Slovene National Theatre, at first as a dramaturg, as its artistic director and then also as the general manager. His first collection of poems appeared already when he was only 21 years old, in 1899, but his interest in drama can be seen from his first short poetic discourse "Vile" (Fairies) which he wrote as a secondary school student and which he published in the magazine for children, Vrtec, in 1895, under the pen-name Smiljan Smiljanič..$^{35}$ This sketch consists of 67 lines and it is written in the form of a rhymed dialogue between three fairies and the choir. The verse is rich in alliteration and imagery and it is thematically linked with fairies from Shakespeare's comedy A Midsummer Night's Dream and a round dance ("kolo"), the country dance which is known in Slovenia in its south-eastern region in Bela Krajina, where Župančič was born. The poet presents fairies dancing in a ring and singing about the good or evil deeds they perform to men. Župančič includes in this sketch a number of images which appear in

\footnotetext{
${ }^{35}$ Vrtec (1895: 145), rpt. in Oton Župančič, ZD (1972:235-237). Joža Mahnič has written several publications on Oton Župančič's life, which are listed below in which he also mentions Shakespeare's influence on Župančič's work.
} 
Shakespeare's comedy mentioned above, such as "spotted snakes", or about people who are "marvellous hairy about the face", people with "an ass's head", or people whom "they frighten out of their wits, if they are evil. On the other hand fairies "bring light to people who are lost", they "make them happy by their chanting, and lull people to sweet dreams"; or, who make them "fearless of beasts, lions, bears", if they are good. This poetic scene ends with the disappearance of fairies. Even though we find these images in Shakespeare's comedy, some of them are also known from Slovene folklore. Župančič's poetic gift is noticeable in this sketch for its composition, rhymes and rhythmical pattern of his verse. Shakespeare's inspiration about fairies is neatly woven in this short dramatic scene.

Although Župančič mainly wrote poetry during the following decades, his love of drama, which he successfully combined with his profession, can be primarily seen in his numerous translations not only of works from English literature but also from dramatic treasury of other European countries. Already in 1931 Tesnière noticed regarding Župančič's literary creativity how closely and mutually influential were his functions as a translator and poet. ${ }^{36}$ But the critic also noticed that the beauty of Župančič's poetry sometimes diminishes its dramatic value. By 1924, when his most important dramatic work Veronika Deseniška appeared in print (it was also performed by the Slovene National Theatre and the premiere took place on 1 December 1924), Župančič had already translated several plays written by Shakespeare as well as plays written by Calderon de la Barca, John Galsworthy, George Bernard Shaw and some other less known dramatists. As a president of three Yugoslav PEN centres he took part at the PEN congress in Oslo and then he spent some weeks in London. At the School of Slavonic Studies he gave a lecture on "Shakespeare in Slovenia", and he also met John Galsworthy there. Župančič's countryman, Janko Lavrin, who was a lecturer of Russian language and literature at Nottingham University, accompanied Župančič to Stratford-on-Avon where Župančič paid tribute to Shakespeare, to this "great genius". In his interview for the Slovene daily Jutro (16 April 1927: 17), Župančič made his well-known statement that "Hamlet is considered by the Slovenes as our best and most beloved popular play."

By 1924 Župančič had translated several plays written by Shakespeare and therefore it is not surprising that one can find several parallels between Shakespeare's plays and direct echoes of his plays in his tragedy Veronika Deseniška. The Shakespeare plays translated by Župančič by that time are: A Midsummer Night's Dream, Julius Caesar, The Merchant of Venice, The Comedy of Errors, Othello, Macbeth. Almost immediately after the production of Veronika Deseniška there appeared his translations of Twelfth Night; Or, What You Will and of The Winter's Tale. Therefore it is not surprising that Shakespeare's impact on Župančič's play may be found primarily in these works and not so much, for example, in other works written by Shakespeare or in Župančič's later translations of Shakespeare (The Tempest, Hamlet, Romeo and Juliet, Coriolanus). Some of his translations of Shakespeare's plays also remained in a manuscript form (Much Ado About Nothing, As You Like It, King Lear, Antony and Cleopatra), although they were performed by the Slovene National Theatre in the 1930s. Oton Župančič was, no doubt, the most important Slovene translator of Shakespeare's plays in the first half of

${ }^{36}$ Tesnière writes: "En matière d'invention verbale, le traducteur a frayé la voie au po te. Et le po te a parfait l'oeuvre du traducteur" (1931: 357). 
the twentieth century. His work was followed after WWII by another poet, Matej Bor, who also prepared the first complete edition of Shakespeare's plays in Slovene language (in a few plays Janko Moder revised the original translation). A new attempt to bring the translations of the Bard into modern, colloquial Slovene was made by Milan Jesih, who has by now newly translated one third of Shakespeare's plays. It should be stressed though that a number of attempts to translate individual plays written by Shakespeare, either only as individual act or scenes or as complete works, date back to the nineteenth century. Dušan Moravec's study (1964: 333-497) still represents the basic source for all further research into this topic.

In addition to Veronika Deseniška Oton Župančič wrote several other plays and dramatic fragments but none of them either achieves the artistic quality of this play or is relevant for the topic of this paper. Župančič treats in Veronika Deseniška the love story between Friderik II, the son of Count Herman II, who is one of the main figures in the history of the Counts of Celje. They were originally the noblemen of a small provincial diet Sovnek and they reached their historical, political and social peak under the rule of Herman II (1385-1434). Herman's son Friderik was married to Jelisava Frankopanska, of a family which were once Croatian vassals of the Venetian Republic and later of the Hungarian Kings. Friderik's relationship with his wife was rather unhappy, and he is said to have had many love adventures before he met Veronika from Desenice. ${ }^{37}$ She was a beautiful young woman coming from a relatively poor Croatian family living in Desenice, not far from Krško. She was a lady-in waiting to Friderik's wife, Countess at Krško, who (according to some sources) committed suicide or was killed by Friderik (according to other sources). Friderik II secretly married Veronika, but when he wished to make her the Countess of Celje, his father strongly opposed that their union become publicly known, because he wished his son to marry into a rich family so that the Counts of Celje would expand their property and their power to the neighbouring lands. Thus Veronika was in his way and he decided to get rid of her either by legal means or by force despite the fact that she was having his son's child. Although Friderik was in love with Veronika his father carried out his plan: he put Veronika in jail and told the Jew Bonaventura to poison her. In Župančič's version of this story Veronika dies of suffering and starvation, although historical facts indicate that she was actually murdered by one of Count Herman's men. Herman II also put his son Friderik to prison, but eventually their relationship was restored. However, the family had no progeny and the Counts of Celje died out in 1456.

There are two main views about the historical role of the Counts of Celje, which was the most important feudal family in the Middle-Ages on the territory where Slovenes are settled. According to the first, the Counts of Celje were raised to the position of the Counts of Celje in 1341. They began to spread their influence towards the East under the rule of Count Herman II, who was followed by his son Friderik; having no projeny, the family died out in 1456 . According to this theory they were not really interested in the Slovenes as a nation; however, at the beginning of the fifteenth century they represented a powerful opposition to the Hapsburg family. Some other historians, though, believe that this family had strong Slavic roots and that it might have joined South Slavic nations

${ }^{37}$ In Croatian "Desinić", a village in Croatian Zagorje, northwest of Zagreb (close to Slovenia). 
in one kingdom had the family survived. Some historians believe that this idea is rather exaggerated and even if the family had survived they would not have been interested in the creation of the Slavic kingdom..$^{38}$ In a recently published book by the Slovene historians Peter Štih and Vasko Simoniti (2009: 128), the authors assert that the Slovenes began to link the Counts of Celje with the Slovenes on the basis of their own political wishes and their needs. Later on, in the second half of the nineteenth century this idea suited the Slovene national programme called "Zedinjena Slovenija" (United Slovenia) and that at the beginning of the twentieth century there arose the idea that if this family had not died out it could have united the nations which created Yugoslavia in 1918. It seems that Oton Župančič was in favour of this idea. Nevertheless it should also be noted that he said a number of times how he was not so much interested in the historical importance of the Counts of Celje, but that his primary interest lay in Veronika's personal fate, in her tragic guilt, and "in the birth of the Slovene soul". Another Slovene dramatist, Bratko Kreft, who also treated this subject in his play Celjski grofje (The Counts of Celje, written and first performed in 1932), opposes both in his play as well as in his introductory essay the idea that this noble family supported Slavic national union. ${ }^{39} \mathrm{Kreft}$ sees the Counts of Celje as supporters of the decaying feudal system, whose main wish was to acquire new lands and more worldly power, as a family which was not favourably inclined towards South-Slavic national tendencies. ${ }^{40}$ The English poet, essayist and playwright T. S. Eliot might have commented upon this question in the following lines: “... History has many cunning passages, contrived corridors / And issues, deceives us by vanities. ... Gives too late / What's not believed in, or is still believed, / In memory only, reconsidered passion" ("Gerontion", 11. 34-36, 39-41). Regardless of the above mentioned differences of opinion of historians about the national consciousness of the Counts of Celje, the three stars which appear in the coat-of-arms of the Counts of Celje, are now included in the coat-of-arms of the Republic of Slovenia.

It is likely that these differences about the historical importance of the Counts of Celje have provided an interesting topic after the creation of Yugoslavia in December 1918, and that this subject-matter has intrigued a number of historians as well as a number of writers of Slovene, Austrian and Croatian background to write historical and literary works about it. ${ }^{41}$ As I have already mentioned, Oton Župančič stressed in his articles and in his diaries that his aim was not to present in his play the exact historical data but that he was interested in the awakening of the Slovene national spirit and in the tragedy of both heroines, Jelisava Frankopanska and Veronika of Desenice. He telescoped the action of the play in the year 1422 (such shortenings of the time span are also usual

\footnotetext{
${ }^{38}$ See, for example, Milko Kos, Zgodovina Slovencev od naselitve do reformacije (1935).

${ }^{39}$ Bratko Kreft, Celjski grofje, Introd. (1979: 22-33).- Kreft's essay was first published in 1932.

${ }^{40}$ Kreft 1979, Introduction, 5-33.

${ }^{41}$ Some of the most important authors and/or titles of works which were used by Župančič are: Eberhard Winecke (1886), Die Cillier Chronik (1883), Aeneas Sylvius Piccolomini (1685), Hieronymus Megiser (1612), Janez Vajkard Valvasor (1685-89), Ignac Orožen (1854), Franz Krones (1871) and Andreas Gubo (1909). Dates in brackets indicate the year when their work was published. See also: Joža Mahnič, in Oton Župančič ZD (1971: 309). Among authors who treated the history of the Counts of Celje are, e.g. Johann von Kalchberg, Ferdo Kočevar, Ivan Detela, Josip Jurčič, Anton Turkuš, Josipina Urbančič Turnograjska, Marica Gregorčič, Josip Evgen Tomić, Anton Novačan, and Anton Aškerc (a poem). The history of the Counts of Celje was also written as a libretto for the operas by Slovene composers Benjamin Ipavec and Josip Švara.
} 
in Shakespeare's histories and tragedies). The play's message is that for the Counts of Celje the search for worldly power was more important than love. Act 1 takes place at Veronika's home at Desenice, Acts 2-4 happen at Krško, at Friderik's castle, and Act V at Gornje Celje, at Count Herman's castle, where Veronika and Friderik are imprisoned. In this historical tragedy Župančič does not stick to the unity of time and place (but neither did Shakespeare in a number of his plays), so that the unity of action is the only one among classical conventions, which is observed in Veronika Deseniška.

Even before Župančič's play appeared on the stage of the Slovene National Theatre in Ljubljana on 1 Dec. 1924, the play was published in summer of this year so that critical views had begun to appear since July. Some of the critics were slightly disappointed with the play and they offered various reasons for their negative reactions, such as that Župančič does not treat contemporary spiritual problems but a historical theme (Miran Jarc); that the play is composed of fragments; that it is full of bathos and its characters are not strong personalities (Stano Kosovel); that the ambitions of the Counts of Celje do not represent the best contrast to Veronika's feelings; that neither Veronika nor Friderik's character is consistent and that the religious imagery is too present (Josip Vidmar). France Koblar saw the play's fault in its abstract presentation of the conflict and in its immoral ethical foundation but also praised some of its features. Ivo Sever criticised the author's verbosity and the weak structure of the play. Some of these points actually appear in several reviews and are presented here in a rather simplified manner. All the critics praised Župančič's poetic gift and they also cited many positive sides thus somewhat minimizing their critical remarks. The negative views were also strongly rejected by some critics, particularly by Fran Albreht, who at first cited his positive views about the play, but who later admitted that Veronika Deseniška was "basically a closet play", i.e. intended for reading. ${ }^{42}$ Although some of these views were rather harsh, the main points about Župančič's predominance of poetic elements over the functionally dramatic language are, no doubt, valid and Župančič obviously admitted the value of some of the criticism by his adaptation of the text for the performance.

Among late responses to the play was Jakob Kelemina's scholarly study in which the author tried to give a balanced view of the artistic value of the play even though he had to repeat some of the negative opinions expressed by other critics (Kelemina 1926). He praises Župančič's choice of the subject-matter but he admits that the history of the Counts of Celje is only partly "real" Slovene history. He states that Veronika Deseniška is written in the manner of the historical tragedy and he deems it natural that Župančič

\footnotetext{
${ }^{42}$ Among English authors whose plays are considered as "closet plays" (intended only for reading) and have been very rarely performed are works by Lord Byron, P. B. Shelley, Alfred Lord Tennyson, Robert Browning, W. H. Auden and Christopher Isherwood, Stephen Spender and Louis MacNeice. Although there are many fine lyrical passages in their plays the plays lack the action required to be successfully staged.

The list of Slovene critics is too long to be quoted here in full; besides, these critics hardly mention in their articles Shakespeare's influence on Župančič. One of the critics, Ivo Sever, even wrote a 79 page critique in which he suggests omissions of the text and rearrangements of scenes in this play. He also compares one of Župančič's characters, the Jew Bonaventura, with Christopher Marlowe's hero in The Jew of Malta, and calls him "an opposition to Shakespare's Shylock in The Merchant of Venice". The play was translated into Serbian, Croatian, Czech, Slovak and German language and several articles also appeared on it in different European countries.
} 
modelled his play on Shakespeare, as a play with "diversified action", i.e. without having the unity of time and place, and with its mixture of tragic and comic features. Kelemina finds Županič's symbolism rather "difficult" and points out that Slovene critics had thus far neglected Veronika's moral guilt, which is also the cause of her personal tragedy. On the other hand, Jelisava is not guilty at all, and Kelemina compares her fate with that of Cordelia, Desdemona or Ophelia, "whose only guilt is their very existence", and which he defines simply as their "existential guilt" (ibid. 501). Kelemina believes that the only real heroic character is Friderik's father, Herman, whose cold, unemotional nature is also the result of Herman's tense relationship with his son. Kelemina praises Župančič's endeavour to present in his play "the national soul", but this author's ambition is too much tied to religious imagery. Likewise, he does not approve of the dramatist's "loose connection between acts", and he also mentions Župančič's "godlike verbosity" (507), which is, unfortunately enough, not always dramatically functional.

More or less the same view was held by Lucien Tesnière who mentions that Župančič's "tyrades lyrique" slow down the action of his play. According to him Veronika Deseniška is written in the tradition, which is very close to Sophocles and the Greek tragedy, whereas in its form and its lyrical expression it can be compared with Shakespeare's plays (1931: 238), and he researched particularly similarities in imagery between Oton Župančič and Maurice Maeterlick, Charles Baudelaire, Paul Verlaine and Walt Whitman.

One of the main Slovene literary scholars in the twentieth century, Anton Slodnjak, also points out that the playwright uses in this work his "witty and brilliant style", but he also regrets that Županič got entangled in Shakespeare's dramatic technique, a point which he repeated a number of times in his histories of Slovene literature (1934: 398; 1938: 15, etc). A long list of critics who have discussed Župančič's play could be supplemented by a number of other well-known names of Slovene critics who also wrote about the play during the following decades (e.g. Fran Mesesnel, Janko Glazer, Božidar Borko, Ludvik Mrzel, Juš Kozak, France Vodnik, Vladimir Kralj), but again, they mainly reported about Veronika Deseniška from the same or very similar points of view to those indicated above and did not take in their perspective possible Shakespearean influence.

Among contemporary critics of Župančič's poetry is also France Bernik, whose study analyzed Župančič's style in his early poetry (1979: 149-163). There he asserts that Župančič became well acquainted with contemporary French symbolism and decadence during his stay in Paris. As we can see some of the elements typical of these literary movements (particularly the metaphoric, poetic language) may also be found in Župančič's play. Several critics have mentioned Župančič's excellent use of blank verse, which Janko Kos links with Shakespeare's versification in Romeo and Juliet (2001: 269), whereas he attributes the slow rhythm of scenes with Goethe's and Schiller's practice.

Župančič's statement that he wished to present in Veronika Deseniška the spiritual drama of its heroes (and of the Slovene nation) and that the history only forms its background leads us to his interpretations of Shakespeare's plays which he was translating in the mid-1920s, at the time when he was writing his own play. He mentions in his diary, in his notes and in the theatre programme the following plays written by Shakespeare which he then admired. They are: Cymbeline, The Winter's Tale and The Tempest. Al- 
though Župančič's discussions about these plays are short, the main "message" which he saw in these plays is nevertheless clear:

The heroes are driven by their passions with an unlimited force (as in his tragedies, M.J.), and the abyss towards which they speed is no less terrifying; mankind would destroy itself had it been fated to outlive the final point of this side of its spirituality. But its recognition, its repentance and its penitence lead mankind to purification and to a higher spiritual sphere, in which miracle, grace and harmony are just as firm truths as the truth of passion, sin and destruction are on a lower level.

(Župančič ZD VIII: 103)

In his appreciation of The Winter's Tale Župančič stresses that the hero's inner suffering in Hamlet, Othello, King Lear and The Timon of Athens could not lead him any further, so that Shakespeare started to look for a solution which he found in his "belief in man and some secret higher power, which lead our ways, to the vision of reconciliation, purification and harmony" (ibid. 104). These are also themes which are relevant for Veronika Deseniška; with one significant change, however: whereas the above mentioned Shakespeare's plays end optimistically, because they are romances, in Župančič's play such an outcome could only be expected in the future due to fact that it is a historic tragedy dealing with the past. Some of the basic ontological concepts which are mentioned here by Župančič are, as we shall see later, characteristic of his heroes.

There are two groups of minor characters present in Veronika Deseniška. The first group form the characters who appear only in Act One, when Veronika is still living at home: Veronika's father ("Deseniški gospod", i.e. the Master of Desenice), her aunt

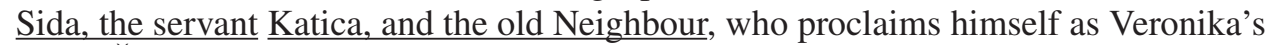
suitor. Župančič portrays Veronika's father in a similar manner as Shakespeare portrayed in his histories some of his characters from lower social strata, e.g. in some ways like

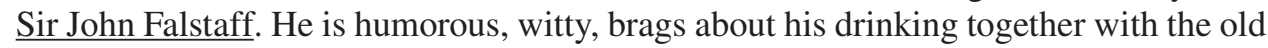
Count Herman, and behaves in a rather haughty manner. But his expression of thanks to his sister Sida's for bringing up Veronika nevertheless sounds too formal, too bombastic; he says: "with one word: thanks for everything" ("z eno besedo: hvala ti na vsem"; 56). ${ }^{43}$ This sounds very much like Claudius' formal manner of speaking (Hamlet 1.2.16) and Župančič may have phrased it in this manner under Shakespeare's influence (Župančič translated Claudius' remark to his councillors in Hamlet "for all, our thanks" (1.2.16) as "Hvala vam za vse" 289). Veronika's father behaves in a patronizing way towards the Neighbour, teasing him that there is no hurry for him to get married ("Par dni še počakaj, da boš mlajši”, 55-6; Wait a few more days, you'll be younger), although he had mentioned in passing that the Neighbour had been Veronika's god-father (51). He also mocks him that he is a "slivar", which was a pejorative term for Croatian popula-

\footnotetext{
${ }^{43}$ Numbers in brackets refer to numbers of pages in Oton Župančič, Zbrano delo VI, (Collected Works, Ljubljana: DZS, 1972) in which Veronika Deseniška is reprinted (pp. 45-223). References to Shakespeare's plays are to acts, scenes and lines as published by John Dover Wilson The Works of Shakespeare (Cambridge: At the UP, first paperback edition, 1968). Slovene translations of Shakespeare's plays are taken from William Shakespeare. Zbrane gledališke igre I, II, III (Collected plays). Ljubljana, DZS, 1978), edited by Matej Bor and dedicated to Oton Župančič on the one-hundred's anniversary of his birth.
} 
tion in the Zagorje region. In Act V, when Herman wishes to prevent Friderik's union with Veronika, he insults her by suggesting that she would miss "rodne slive" (180), "her native plums", i.e. her village, her old environment. The theatre audience becomes acquainted with Veronika's social background but the only important dramatic character among them is Veronika's father, but neither he not other minor characters appear later on in the play. Therefore - as a number of Slovene critics have suggested - this act could be easily omitted or some characters should be reintroduced in the play later on.

Veronika's aunt Sida is modelled on Juliet's Nurse in Shakespeare's Romeo and $\underline{\text { Juliet }}$ in a number of aspects: as regards her function in the play, her behaviour and her use of language. Sida is a warm-hearted person, she has brought Veronika up and she thinks - like the Nurse in Romeo and Juliet - that she has to plan Veronika's future. Sida even uses the same kind of imagery as the Nurse: she calls Veronika a "dove" whom she will look after until "the right falcon comes to take her" ("ko pride pravi sokol po golobico", 50). Sida's language is elevated and it often surprises the reader with its poetic beauty; for example, when she tells the maid Katica how Veronika looked like in her sleep:

$$
\begin{aligned}
& \text { Metulji-sanje } \\
& \text { so vztrepetavali ji na očeh, } \\
& \text { obotavljaje se zleteti z njih. (47-8) }
\end{aligned}
$$

(Butterflies-dreams / were (still) twittering on her eye-lids / hesitating to fly away.)

The Nurse finds Juliet "the prettiest babe that e'er I nursed" (1.3.61), and like Juliet Veronika was also breast-fed by Sida (57). Sida calls Veronika "rahel cvet" (a tender blossom, 54) and "nebogljenče" (a fragile child, 56) and the Nurse laments over Juliet's fate "What, lamb! What, lady-bird" (1.3.3). Sida has knitted a coat which Veronika will present as a gift to her mistress. Veronika's father observes that Sida also knitted three stars on a grey surface, which appear in the coat of arms of the Counts of Celje and Sida tells him that she wishes to bring Veronika under these stars. He also notices that the cloth Sida used is like a spider's web ("pajčevinasta tkanina", 60). This image has a double connotation: the coat is made of fine tissue which befits a lady of high social rank, and at the same time it foretells Veronika's future, she will be caught in the family relations of the Counts of Celje like "an insect".

The Nurse in Romeo and Juliet lives long enough to see Juliet "dead" after Juliet had taken the sleeping potion ("Why, lamb! why lady", 4.5.2), and neither the Nurse nor Sida can protect her protégée from the fatal consequence; however, the Nurse's role is much more complex and as regards the heroine's tragedy more regrettable. But if we take all the minor characters in Act One in Veronika Deseniška into consideration we see that they are dramatically rather unimportant. If Veronika's father had appeared later on in the play he could represent (together with his daughter) a social contrast and a counterpart to the powerful family of the Counts from Celje.

The second group of minor characters are the two knights (Jošt Soteški and Ivan Sevničan) and Nerad, the steward at the Krško castle. Although they appear at first to be Friderik's companions and friends, they know that the real power lies in Herman's hands; Jošt, who among them was emotionally closest to Friderik, is even commanded 
by Herman to become Veronika and Friderik's gaoler. As far as their social role is concerned they belong to the hero's friendly "advisors", but after the climax when the old Count Herman brings the situation under his control they no longer crack jokes about Friderik's love as they did before (when e.g. Jošt ironically asks Friderik if now that he is in love he is going to "the desert" and would therefore not be going to pursue his enemies any longer, 72-3). Nerad tells his companions that Friderik is always in such a hurry to go and see Veronika and that "he would complain he was riding a snail"(77). Friderik's companions also use a pet-name for him and call him "Bedrik" (74-5 etc.; this may be a pun referring to Friderik's "silly" behaviour, or to Veronika's legs, to her thighs; "bedro" is "thigh" in Slovene) ${ }^{44}$. Jošt makes fun of Herman's view that Veronika is an angel, a god-like creature: "Svet, na kolena! Kdor nje ne časti, / je nejevernik in očitni grešnik" (74; The world, down on your knees! A man who does not worship her / is an infidel or an obvious sinner). But Friderik's men know, as Jošt says, that Friderik's father Herman will soon learn about Friderik's affair, because Herman is like "god's-eye", seemingly looking nowhere, but seeing everything ("On ti je božje oko: / uprto kot nikamor, vidi vse.", 78). Jošt admits to Friderik that he serves both "the sun" and "the moon", but he does this regarding the "heavenly constellation" (103), i.e. that he obeys both Count Herman and Friderik, just as Falstaff and his companions try to obey their master. When the knight Jošt is told by Count Herman to be Friderik's gaoler he wishes to make a remark but Count Herman stops him and Jošt then apologizes to Friderik that he will not be performing a friend's job ("to služba ni prijateljska", 198); but Friderik tells him he should do what he must do. Friderik's "companions" do not have the wisdom of the Fool in King Lear and do not make such witty remarks; when they ridicule Friderik and when they make fun of him they are more like Sir John Falstaff, Gadshill, and Bardolph in the First Part of King Henry IV.

Although Friderik tries to oppose his father, when Count Herman tells him not to make his marriage with Veronika publicly known, Friderik still insists that they are married. But he is a weak character and therefore less tragic than his wife Jelisava or Veronika. He breaks down under his father's domination and functions more like a grown-up Romeo than like one of Shakespeare's great heroes. But he does realize that Veronika now represents to him the highest value in life and that he had not done enough to rescue their love. Therefore he is left at the end of the play with inner emptiness, in despair, knowing that he will never by the same and that he had lost his integrity. "A tu mene je brezna v sebi strah." (235, And here / now - I am afraid of the abyss in me.). ${ }^{45}$ Although Friderik's love for Veronika can be compared here with Othello's love for Desdemona (before Othello starts to doubt her honesty and sincerity), Herman's short monologue at the end of the play easily persuades the reader that Herman is right and that Friderik will eventually give up his position and that time will heal their quarrel (223). Herman's wish always to have the last word, and particularly his cruel behav-

\footnotetext{
${ }^{44}$ In Jurčič's version of Veronika Deseniška Veronika and count Herman call Friderik "Fric" (1960: 93-7), which is not the case in Župančič, most probably because this is also in Slovene a pejorative form used for a German soldier (SSKJ 1994: 225).

45 Župančič uses here the word "brezno" (the abyss), which he also used in his notes and observation about the growing despair of Shakespeare's heroes in his great tragedies (Župančič ZD VIII: 103-104).
} 
iour to Veronika, can be best compared with the behaviour of some of Shakespeare's heroines, particularly by their obsession with power and evil, as for example, by Lady Macbeth and by Goneril and Regan in King Lear. However, Herman does use Othello's type of sharp, biting language and his rhetoric when he wishes to subdue Veronika. When Friderik tells his father that Veronika is his legal wife, Herman calls her "a whore from Desenice" ("Vlačuga z Desenic", 192), just as Othello refers to Desdemona ("I took you for that cunning whore of Venice / That married with Othello", 4.2.90-91). Or, Count Herman accuses Veronika that she is "a moth who has enchanted you all, / a whore preparing intrigues against the Counts of Celje ("Ta vešča vas je vse očarala, / vlačuga, ki se plete za Celjani." (192; in Slovene "vešča" is a euphemism for "whore, prostitute"). Count Herman also wishes to persuade an old public Judge ("Pravdač") that Veronika had bewitched Friderik's heart and mind, and if this is so he could imprison her "justly" ("spoznati mora, da je otrovala / sinu srce in um s čarobami", 202). This kind of accusation of witchcraft is also made by Desdemona's father Brabantio against Othello ("Damned as thou art, thou hast enchanted her", 1.2.63). But when the old lawyer tells Herman that he has not found any evil power in Veronika and that Friderik was only "charmed by her youth, beauty and kindness" ("Čaroba njena je le očarljivost / mladosti in lepote in miline", 206), and that their only sin is their "mighty love" ("Ljubezni silni pala sta v oblast, / to jima je ves greh", ibid.), Count Herman proves with his unjust act (i.e. by sending Veronika and Friderik to prison) that he considers himself to be above the law, that he is really an immoral tyrant. When the Judge warns Count Herman that "power without justice is tyranny" ("in sila brez pravice je nasilje", 208), Herman immediately sends the Judge away, because "he knows what he wishes to know" (ibid.) The whole scene with the old judge who had been summoned to the "court" to hear and to decide Veronika's fate, is built on Shakespeare's scene of the Court of Justice in The Merchant of Venice (4.1), with one major distinction which is based on the nature of Župančič's play: Veronika and Friderik are unjustly sentenced, whereas Portia in The Merchant of Venice, dressed as a doctor of civil law, cleverly denies Shylock his "right" to cut off a pound of Antonio's flesh. When she tries to persuade Shylock to be merciful she says:

The quality of mercy is not strained,

It droppeth as the gentle rain from heaven

Upon the place beneath. It is twice blessed:

It blesses him that gives, and him that takes,

'Tis mightiest in the mightiest, it becomes

The thronéd monarch better than his crown. (4.1.181-86)

But Župančič wrote his play as "a tragedy" whereas The Merchant of Venice is entitled as "The most excellent Historie", and modern critics usually refer to it as Shakespeare's "High (Early) Romantic Comedy". We can compare Count Herman's behaviour with that of Leontes in The Winter's Tale who does not accept Apollo's verdict that his wife Hermione is chaste; he says:

There is no truth at all i'th'oracle:

The session shall proceed; this is mere falsehood. (3.2.139.40), 


\section{And Count Herman:}

Nič, proč. Naprej. - Torej po pravdi ne.

Ne pred sodnike ... Vendar mora biti. (209),

(No, away. Continue. - Then: not according to justice. / Not by judges. .. But it must be so.)

Župančič supports Friderik's argument about his love for Veronika by Friderik's double negations, which he uses when he wishes to persuade her that he did not "betray" her with his wife Jelisava. He calls God as a witness and his inexorable demand that love is based on man's sacrifice, on the offering of lovers' hearts as a proof of their love (cf. Gen. 22, when Abraham is blessed by God after he had offered his son Isaac to him). Friderik says:

Je preveč ljubiti greh, Veronika? ...

/Srce/ je bilo samó še žgavni dar

pred nespravljivim, neizprosnim bogom,

ki ne živi, če ne gorijo srca

pod njim v plamenih žarkih? (145)

And Veronika answers Friderik with rhetorical questions about the future, in which there is a clear division between the existence of the world and her fate: the world will go on, but she is going to be damned and excommunicated both from physical and heavenly, spiritual life:

Bo jutri dan? Bo sonce? O - vse bo:

dan, sonce, svet, ljudje po svojih poslih...(146)

Le jaz prokleta in izobčena

iz smrti in življenja in vseh poslov

tega in onega svetá ...Kam bi? (146)

This passage is one of many examples in this play in which the dramatist uses alliteration and consonance (e.g. the repetition of "s" in sonce, svet, po svojih poslih etc.). These are not very common metrical figures in Slovene, but when translating Shakespeare's plays Župančič must have observed how frequently and how effectively they appeared in English. Župančič is known for his rich use of rhymes, although Slovene critics have not stressed yet enough his numerous examples of alliteration and assonance which can also be found in his poetry as well as in his play.

As a proof of his love for Veronika Friderik offers her a bodkin to kill him if she does not believe that he really loves her and the baby she is bearing:

Primi, potisni!

Glej; tukaj bije, zate in zanj, za drobno

čebelico - in vaju je izdalo .... (147)

There is a similar situation in King Richard III when the Duke of Gloucester (later King Richard III), who killed Lady Anne's husband (!) tries to prove "his love" for her by offering her his sword: 
And let the soul forth that adoreth thee,

I lay it naked to the deadly stroke,

And humbly beg the death upon my knee. (1.2.176-78)

Both ladies find themselves in a difficult situation: should they trust men who proclaim their love for them or should they follow their instinct and reject their proposals. Although Anne in King Richard III does not trust Gloucester and she tells him that "though I wish thy death, I will not be thy executioner" (1.2.184-85), but she nevertheless allows herself to be persuaded by Richard's cunning talking and she accepts his ring. Veronika makes a few short contradictory statements about her feelings for Friderik, but she admits her paradoxical situations: she loves him (she uses her pet name "Inko" for Frideri,k) and she hates him too:

Prokleta sem, pogubljena: ljubim te.

In te sovražim, veš, sovražim strašno.

In vsa sem tvoja - Inko, Inko moj ...(147)

Župančič knew Shakespeare's presentation of Othello's doubt about his love for Desdemona, ${ }^{46}$ his love-hatred relationship, in which Othello says that without Desdemona's love his life would be meaningless; Friderik's conclusion is the same.

Excellent wretch! Perdition catch my soul

But I do love thee; and when I love thee not

Chaos is come again. (Othello 3.3.91-3)

In The Winter's Tale Leontes, King of Sicilia, suspects that his wife Hermione has betrayed him with King of Bohemia, Polixenes, and he tries to persuade Camillo, one of his lords, that then there is no meaning in life for him because she had supposedly betrayed Leontes. He "quarrels" with Camillo:

Is this nothing?

Why then the world, and all that's in't, is nothing,

The covering sky is nothing, Bohemia nothing,

My wife is nothing, not nothing else have these nothings,

If this be nothing. (1.2.292-96)

Iago uses as his argument for Desdemona's infidelity a number of events and situations which cannot be objectively proved and a "fact" which is not true ("She did deceive her father, marrying you", 3.3.208), because Desdemona married Othello out of true love. Veronika sees as a possible proof against Friderik in the fact that he had "deceived" his wife Jelisava when he made love to her. Before her death, Desdemona sings a ballad which her mother's maid Barbara used to sing after her lover had left her, because she has a premonition of her demise. (4.3) Veronika prays in her poetic monologues to God for help (214-216, 220-221) just as Desdemona denies her guilt and hopes to be saved by God $(4.2,5.2)$. Desdemona tells Emilia, "A guiltless death I die", when she is asked by

${ }^{46}$ Othello was the first play written by Shakespeare to be translated into Slovene by M. Malovrh and performed at the Slovene National Theatre in Ljubljana on 1 March 1896. Oton Župančič prepared another translation of this play in 1920. It was published in 1923 and first staged at the SNT on 7 March 1925 a year after he had written Veronika Deseniška. 
Emilia who had committed the crime she wishes to exculpate Othello and answers her, "Nobody. I myself" (5.2.24-26) Similarly, Veronika asks Bonaventura to tell Friderik that she has also taken upon herself everything, / all that night, her own and his part / on her soul, ".. povej mu, da sem vzela nase vse - / vso tisto noč, veš, svoj in njégov del / na svojo dušo". (220) Both heroines are on a morally higher level than Othello and Friderik. The similarity between the acts of both lovers, of both scenes, is obvious. Veronika's admission of her guilt links her with moral solutions of Shakespeare's heroes in his romances, which Župančič admired so much in the early thirties.

The portrait of Jew Bonaventura is in a number of ways like that of Shylock in Shakespeare's The Merchant of Venice, although his role in the plot of Veronika Deseniška is much more limited. He serves his masters, Friderik, Jelisava and Herman without any moral prejudice. He brings poison to Jelisava which is not like the sleeping potion which Friar Lawrence provides for Juliet (4.1); poison is only used in Shakespeare's plays by evil characters (e.g. lady Macbeth kills herself; Goneril poisons Regan in King Lear). Herman demands that Bonaventura should poison Veronika, and when Veronika asks him why he came to her cell he tells her that he wishes "either his or her death" when the candle light will be extinguished (217-18). But he does not tell her that actually there is no choice for Veronika because Herman had promised Bonaventura freedom for poisoning Veronika, and death to him if she did not die (213). Bonaventura tells Veronika that he has not yet murdered anybody, and Veronika's quick and sudden death brings him a relief: Herman allows him to leave freely (222). Župančič does not create in the Jew Bonaventura a one-sided, completely negative picture but endows him with some goodness too (e.g. he laments over Veronika's death, comparing it to "the destruction of God's temple", ibid.). In this way the behaviour and the emotions of an individual, Bonaventura, become more important and individualized than his Jewish race.

Župančič creates in Herman a double personality who preaches one thing but believes in something else. When Herman writes a letter presenting donations to various monasteries he tells Friderik that our worldly matters, if compared with eternity, are only dust and air that is blown away by the wind ("posvetnost naša / je proti večnosti le prah in puh, / ki veter ga raznese in razstelje", 97) and what really counts in life are the acts of "Christian charity". But when Friderik esteems Veronik's love more than the property of the Counts of Celje, Herman's response is built on an image how the eagle builds its nest high up in the mountains, ("Orel si plete gnezdo na visokem", 190). This statement can be paralleled with the observation made by King Henry VI (2.1.8), in the second part of his trilogy, when he says, "Yea, man and birds are fain of climbing high", which was translated by Župančič as "Človek in ptič prav vse stremi navzgor". Herman's dream to place the family of the Counts of Celje higher and higher on the social scale by means of a "proper" marriage of his son Friderik is ruined when Friderik insists that his marriage with Veronika is legal. But Herman does not give up his ambition to win this game to acquire new lands with Friderik's help. Some of Shakespeare's kings are just as ambitious as Herman, however, an even more plausible parallel can be made with one of Shakespeare's heroines, especially with Lady Macbeth, who is prepared to sacrifice everything in order to fulfil her dreams for power even if her life is built on crime. 


\section{BRATKO KREFT: CELJSKI GROFJE (THE COUNTS OF CELJE, 1932)}

The essence of Bratko Kreft's attitude to the ethnic, national and political position of the noble family of the Counts of Celje has already been indicated in the preceding section in connection with the historical role of this family as it was seen in a number of historical treatises written by Slovene and other historians and in the poetic version in Oton Župančič's Veronika Deseniška. In his version Kreft concentrated on the judicial process about this tragic heroine and its social implications. Although the majority of influences of Shakespeare's plays on Kreft's drama are not direct, the impact of his history of King Henry VI can be easily noticed in its construction, its selection of themes and presentation of characters. Kreft's play was first produced by the Slovene National Theatre (Drama) in Ljubljana on 17 September 1932. Due to its straightforward discourse and its tight dramatic structure the play was favourably received by Slovene critics (e.g. Boris Ziherl, Josip Vidmar, France Koblar etc.) and also by the public.

The action of Kreft's play spans during two days in 1428, when Veronika Deseniška is tried as a witch at the castle of Celje, set free by the court and murdered by the order of Count Herman immediately after the trial. Although her guilt as a witch is not proved, Count Herman, the eldest and the most influential member of the family, decides that Veronika must disappear so that his son, Friderik, can be pardoned of the murder of his wife, Elizabeta Frankopanska. By getting rid of Veronika, Friderik's marriage with her will no longer influence his future and the possibility of his new marriage in the nobility. But the Judge who is to defend Veronika is persuded that Veronika is innocent and he does not succumb to Count Herman's pressure and wins the trial. Nevertheless Herman also orders his imprisonment and the Judge, who may have been Herman's bastard son, commits suicide. In spite of Herman's endeavours to preserve the power of the family it is obvious that their power is vanishing.

In his notes to the play Kreft points out that at the beginning of the fifteenth century a number of important historical events had occurred in Europe. In Bohemia - which was then, together with Hungary, a part of Austro-Hungarian Empire - a reformist social, religious and national movement was led by Jan Hus, who was burned as a heretic in 1415. England was in a war with France where Joan of Arc compelled the English to lift the seige of Orleans in 1429; there was religious and social unrest in central Europe etc. Kreft obviously sees in this framework the historical development in Styria, which was also a part of the Austro-Hungarian Empire, and where the Counts of Celje attempted to acquire new territory, both in Hungary as well as in the Slavic (Croatian and Bosnian) lands. Shakespeare presented such social unrest particularly in his history King Henry $V I$, where rebels like Jack Cades opposed the King, but were also cruelly suppressed. Kreft sees the social and historical position of Count Herman as the defender of the old feudal order who will, as he tells the Judge, ".. use all his wisdom, power and property to suppress [the rebels, M.J.] so that your serfdom is a warning to your descendants ..." (Kreft 1979: 85). A growing opposition to the Counts of Celje is also represented in this play by the Citizens of Celje (merchants, tradesmen, bakers, priests, armourers etc.) who are not (yet) united although many of them see injustices done by the nobility and - at least half-heartedly, because they are still afraid of the nobility - support the Judge and his defence of justice. This group of citizens plays an important role in this tragic 
history, but their voice is becoming louder and it is heard more often than the voice of citizens (or rebels) in Shakespeare's King Henry VI so that antagonisms between feudal lords and the rising bourgeoisie are more visible. Like their historical protagonists in fifteenth century Europe, they attack the attempts of the Church to acquire more property, and they demand its return to "evangelical poverty". They mostly disapprove of Queen Barbara's flirting with the Duke Eneas Silvius Piccolomini whose role as a plaintiff in Veronika's trial is completely partial and dishonest. ${ }^{47}$

Kreft's presentation of some characters, particularly of Veronika and Friderik, differs from Župančič's portrayal: in Kreft's play Veronika is a much more witty, energetic and eloquent character than her counterpart in Veronika Deseniška, and like Desdemona she also accepts Friderik's guilt. Veronika also fell in love with Friderik because of his courage (like Desdemona) and also because she admired his reputation as a womanizer. She is prepared to suffer the consequences of the trial rather than betray her love. The trial scene in Kreft's play does not echo only the trial scene in Shakespeare's The Merchant of Venice but also the trial scene in G. B. Shaw's play Saint Joan (1924). It was translated by Oton Župančič, produced by the Slovene National Theatre in Ljubljana and directed by Bratko Kreft (!). Its premiere was on 27 Sept. 1933, a year after the production of Kreft's play. In his Introduction to Celjski grofje (The Counts of Celje) Kreft mentions the role of Joan of Arc; if we take into consideration the structure of both trial scenes, the time of the production of Saint Joan and Kreft's role in it we can agree with Slovene literary historians that also the influence of Shaw's play is obvious.

The central characters in Kreft's play are Veronika, old Count Herman and Veronika's defendant the old Judge, who is Herman's mighty antagonist and whose personal integrity can never be questioned. This is also seen in his decision to commit suicide rather than be Herman's prisoner. He is an excellent parallel to Portia and to her rational defence of Antonio in Shakespeare's The Merchant of Venice (4.1). The Judge also expresses the author's views and his ideas which announce a new social and political order.

The sensuality of Queen Barbara, Friderik's daughter, who is married to the King of Hungary, can be compared with that of Goneril and Regan in Shakespeare's King Lear; what matters to her is her sensual enjoyment, her desire for constant sexual variety, which she does not find immoral. She denies life after death, and she expresses her atheistic persuasion by saying, "There is nothing after death." (Kreft 1979: 90) Similar views are expressed by Macbeth after King Duncan's murder, when he states: "There's nothing serious in mortality: / All is but toys .." (2.3.92-3); or, "Life's but a walking shadow, a poor player / That struts and frets his hour upon the stage, / And then is heard no more ..." (5.5.94-6). The lack of Christian belief and moral codes is - in some of Kreft's heroes - in agreement with their apprehension of the meaninglessness of life as it is declared by the protagonist in Shakespeare's Macbeth.

\footnotetext{
${ }^{47}$ Enea Silvio Piccolomini (1405-1464); lawyer, poet, historian, secretary to various religious dignitaries, cardinal, in 1458 elected as Pope Pius II. In his histories he mentions the Counts of Celje, beautiful and lascivious Friderik's daughter Barbara, to whom he attributes atheistic belief (together with her father Friderik and his son Ulrik). Both dramatists, Oton Župančič and Bratko Kreft, were familiar with Piccolomini's work. (See: Joža Mahnič in O. Župančič's Zbrano delo VI (1972): 308-309; and Bratko Kreft, Introduction to Celjski grofje (1979): 28-29.). - Piccolomini led in his youth a dissipated life, but in 1444 he turned to Christianity. - In 1462 he founded the bishopric of Ljubljana.
} 
In Kreft's Celjski grofje (The Counts of Celje) a more down-to-earth picture is provided by the author than in Župančičcs Veronika Deseniška (Veronika of Desenice); however, in Župančič's play the characters receive a more subtle and a more universal dimension. Kreft is closer to Shakespeare as regards the composition of the play and its direct message, whereas on the other hand, Župančič's rich poetic language diminishes the scope of the subject-matter of his play but at the same time provides the play with greater aesthetic beauty. Although both Župančič and Kreft tried to follow the path provided by Shakespeare in his plays, paradoxically enough, their "strong points" lead them away from their Master.

\section{CONCLUSION}

One of the main results of this research is the fact that Slovene dramatists writing in the second half of the nineteenth and the first decades of the twentieth century were much more familiar with Shakespeare's plays than was surmised until now. This is evident from some direct "borrowings" of scenes, characters, motifs, and figurative language as well as from many allusions and parallels which can be found between Shakespeare's plays and plays which I have discussed here.

Josip Jurčič and Fran Levstik were both great admirers of Shakespeare's work, which can also be seen in their versions of Tugomer. In Jurčič's version the echoes of Hamlet and Othello are particularly noticeable, whereas in Levstik's version similarities between Shakespeare's heroes are also quite numerous (e.g. in Macbeth, Julius Caesar, King Richard III, King Henry IV, Romeo and Juliet) but these influences are much more artistically and philosophically interwoven in Levstik's text than those in Jurčič's version. This evidence also shows that neither Jurčič nor Levstik modelled their hero only on Coriolanus but that they combined various motifs, construction of scenes and their protagonist on a wider scale of sources from Shakespeare's plays.

In Cankar's play Kralj na Betajnovi (The King of Betajnova) the most easily recognized influence is "the mouse-trap" scene from Hamlet as well as his portrayal of several main characters (Kantor, Maks Krnec and his father, Francka, Ana), whose characters are very similar to major characters in Hamlet. The episodes in Act One in Cankar's play particularly show Cankar's debt to Shakespeare, and Maks's character is obviously based on Shakespeare's hero, on Hamlet. The parallels between Shakespeare's plays and Cankar's farce Pohujšanje v dolini Šentflorjanski (Scandal in the Valley of St. Florian) are mainly in love scenes, which remind us of Romeo and Juliet and Hamlet and also with symbolism of The Tempest, although the symbolic features may only be incidental. The third play written by Cankar (together with its fragments) discussed here is Lepa Vida (Beautiful Vida), for which Cankar found the inspiration in Shakespeare's Hamlet. In this case there are not only similarities in character presentation which link both play, but especially the authors' philosophy as it is shown in these plays. Mile Korun's adaptation of Cankar's texts, his rearrangement of individual passages, represents his contribution to its dramatic qualities, although Cankar's poetic text shows even more clearly than Župančič's tragedy the shortcomings of the extensive use of poetry in dramatic art. 
Oton Župančič was well acquainted with Shakespeare's plays as a translator, theatre director and theatre manager. He valued Shakespeare's plays extremely highly, not only his 'great tragedies' but also his histories and his late romances (Cymbeline, The Winter's Tale, The Tempest), in which he found ethical values missing in 'the story' of his own play, Veronika Deseniška, such as "reconciliation, purification and harmony". But in his play even positive solutions, which we find in Shakespeare's The Merchant of Venice, become negative. The world of Veronika Deseniška is dominated by catastrophes similar to the ones appearing in Romeo and Juliet, Othello, King Lear, King Richard III and therefore echoes from these plays are noticed in Župančič's play too. Even though there are numerous parallels between these plays and Župančič's tragedy, his poetic imagination results in this tragedy in great artistic beauty which, unfortunately, prevails over the dramatic tension of his play. Compared with Župančič's play Kreft's Celjski grofje is a realistic problem play, in which we do not find the poetic beauty of Župančič, but therefore Kreft's play is more likely to be accessible to broader public and its plot can be more easily followed than in a "poetic play". Kreft was definitely more impressed by Shakespeare's histories than by his other plays.

In Shakespeare's tragedies evil characters do not win, and although many innocent people are also killed there is always at least some hope left in his plays that the future will bring about a better world. On the other hand, Slovene tragedies, which I have discussed here, do not have an optimistic ending. Such bleak conclusions were probably mainly the result of the historical, political and social situation at the time when these plays were written. Nations which domineered over the Slovenes during the past centuries were not particularly in favour of Slovene liberation and independence, which can be seen in various kinds of political and social oppression and in this particular field, in drama, in the theatre censorship. Since 1991, when Slovenia became an independent state our fate is mainly our own responsibility, and a number of weaknesses which these artists have shown in their plays, are still as acute as they were one hundred and fifty years ago. But Slovene artists still hold the mirror up to nature and therefore these plays should also be performed more often in spite of their shortcomings. The comparison between Shakespeare's plays and Slovene plays discussed in this paper shows that although Slovene authors used Slovene myths in their plays they tried to make them universal. Although they "borrowed" various thematic or theatrical details from Shakespeare's plays they were conscious that their works should primarily appeal to their own people. Slovene dramatists justly admired this great author and his plays and in many cases they successfully adapted both Shakespeare's vision of social and political life and his aesthetic treatment of different fables and histories to their own cultural situation. Inspiration they got from Shakespeare was thus often successfully transformed into new works of art. 


\section{WORKS CITED}

Aristotle. Poetics. Trans. and ed. Kenneth A. Telford. Chicago: A Gateaway Edition, Henry Regnery Co., 1970.

Bernik, France. "Slogova modernost Župančičevih zgodnjih pesmi." Župančič, Oton. Simpozij (1979): 169-163.

Cankar, Ivan. Zbrano delo IV. (Kralj na Betajnovi. Pohujšanje v dolini šentflorjanski. Hrepenenje.) Ed. Dušan Moravec. Ljubljana, DZS, 1968. 5-66. 67-121. 125-138.

Zbrano delo V. (Lepa Vida. Nioba. Hamlet iz cukrarne.) Ljubljana: DZS, 1969. 67-110. 115117. 118-131.

Cankar, Ivan, Mile Korun. Lepa Vida. Hrepenenje - Hamlet iz cukrarne. (Konstrukcija prizorov.) Ljubljana: Gledališki list Mestnega gledališča Ljubljanskega, 524 (2001-2002): 77-100.

Copeland, F. S. "O Župančičevih prevodih Shakespearja.” Ljubljanski zvon 1926: 161-170.

Grošelj, Nada. "Two $17^{\text {th }}$ century Jesuit plays inspired by English Literature." Acta Neophilologica 37.1-2 (2004): 61-71.

Halliday, F. E. A Shakespeare Companion. 1564-1964. Penguin books, 1964.

Jack, Ian. English Literature. 1815-1832. The Oxford History of English Literature. Vol. 10. Oxford: OUP, 1963.

Jurak, Mirko. "Vloga in pomen virov za Shakespearovo dramatiko." W. Shakespeare. Zbrana dela. Ed. Matej Bor. Ljubljana: DZS, 1974. 499-545.

Od Shakespeara do naših sodobnikov. Ljubljana: ZIFF, Partizanska knjiga, 1983.

"The English Romantic Movement and France Prešeren." Prešernovi dnevi v Kranju. Ed. Paternu, Boris, et al. Kranj: Mestna občina Kranj, 2000.

"Some Additional Notes on Shakespeare." Acta Neophilologica 38.1-2 (2004): 3-48.

"Jakob Kelemina on Shakespeare's Plays." Acta Neophilologica 40.1-2 (2007):4-49.

"William Shakespeare and Slovene Dramatists (I): A. T. Linhart's Miss Jenny Love." Acta Neophilologica 42.1-2 (2009): 3-34.

Jurčič, Josip. Zbrano delo IX. (Tugomer. Veronika Deseniška.) Ed. Mirko Rupel. Ljubljana: DZS, 1960. 7-64. 65-123.

Kalan, Filip. "Obris gledališke zgodovine pri Slovencih.” Novi svet III. Ljubljana, DZS, 1948.

Kelemina, Jakob. “O Veroniki Deseniški.” Ljubljanski zvon 46.7-8 (1926): 495-508.

Kermauner, Taras. Slovenska dramatika-modeli. Aksiološke in metodloške teme. Ljubljana: Filozofska fakulteta, 1988.

Kmecl, Matjaž. Josip Jurčič. Pripovednik in dramatik. Ljubljana: Zavod RS za šolstvo, 2009.

Koblar, France. "Shakespearov dramski in pesniški slog." Shakespeare pri Slovencih. Ed. F. Koblar. Ljubljana: Slovenska matica, 1965. 121-175.

Slovenska dramatika I, II. Ljubljana, SM, 1972, 1973.

Korun, Mile. "Dnevnik." Cankar, Ivan, Mile Korun 2001-2002:57-74.

Koruza, Jože. Slovenska dramatika od začetkov do sodobnosti. Ed. Kocjan, Gregor, et. al. Ljubljana: Mihelač, 1997.

Kos, Janko. Predromantika. Literarni leksikon 31. Ljubljana: DZS, 1987.

Leksikon Slovenska književnost. (1982) Ljubljana: CZ, 1996.

Primerjalna zgodovina slovenske literature. Ljubljana: MK, 2001.

Kos, Matevž. Poskusi z Nietzschejem. Ljubljana: SM, 2003.

Kreft, Bratko. Celjski grofje. 1932. Introd. B. Kreft. Afterword Dušan Moravec.Ljubljana: Mladinska knjiga, 1979. 35-101.

Levstik, Fran. Zbrano delo V. (Tugomer.) Ed. Anton Slodnjak. Ljubljana: DZS, 1955. 59-218.

Levstik, Fran - Bratko Kreft. Tugomer. Ljubljana: DZS, 1967. Ed. and introd. B. Kreft (3-23) and France Koblar 201-227). Ljubljana: DZS, 1967.

Mahnič, Joža. Zgodovina slovenskega slovstva V. Ljubljana, Slovenska matica, 1964. 
. Oton Župančič. Ljubljana: DZS, 1998.

Menart, Janez. "Nekaj misli o Župančičevih prevodih Shakespearovih dram.” Oton Župančič v prevodih. (Zbornik Društva slovenskih književnih prevajalcev 4.) Koper: Založba Lipa, 1980: 88-92.

Moder, Janko. "Ivan Cankar prevajalec." Ivan Cankar v prevodih. (Zbornik Društva književnih prevajalcev Slovenije.) Murska Sobota: Pomurska založba, 1977: 47-64.

Moravec, Dušan. “Shakespeare pri Slovencih.” W. Shakespeare. Zbrana dela. Ed. Matej Bor. Ljubljana: DZS, 1964. 333-497.

"Dramaturško delo Otona Župančiča." Župančič (1979): 91-106.

Nabergoj, Irena Avsenik. Ljubezen in krivda Ivana Cankarja. Ljubljana: MK, 2005.

Paternu, Boris. France Prešeren in njegovo pesniško delo. 2 vols. Ljubljana: Mladinska knjiga, 1976, 1977.

Pisma Ivana Cankarja. I-III. Ed. Izidor Cankar. Ljubljana: DZS, 1948.

Pogačnik, Jože. Slovenska Lepa Vida ali hoja za rožo čudotvorno. Ljubljana: CZ, 1988.

Poniž, Denis. Ivan Cankar - Lepa Vida. Ljubljana: SGM, 2006.

Prešeren, France. Zbrano delo 2. Ed. Janko Kos. Ljubljana: DZS, 1966.

Sever, Ivo. Oton Župančič. Zagreb: Knjižnica Naša gruda, 1. jan. 1928.

Shakespeare, William. The Works of Shakespeare. The New Shakespeare. 37 vols. Ed. John Dover Wilson. Cambridge: At the U. P., 1968. (The collection includes all Shakespeare's plays and poems and references to the original text in the study are made to this edition.)

Slodnjak, Anton. Pregled slovenskega slovstva. Ljubljana: Slovenska matica, 1938.

Zgodovina slovenskega slovstva III. Ed. Lino Legiša. Ljubljana: Slovenska matica, 1961. Slovensko slovstvo. Ljubljana: MK, 1968.

Slovar slovenskega knjižnega jezika (= SSKJ). Ed. Anton Bajec et al. Ljubljana: SAZU, DZS, 1994.

Slovenske ljudske pesmi. Ed. Marjetka Golež Kaučič et al. Ljubljana: SM, 2007.

Slovenske narodne pesmi I. Ed. Karol Štrekel. Ljubljana: SM, 1895-1898.

Stritar, Josip. Zbrano delo VI. Ed. France Koblar. Ljubljana: Državna založba Slovenije, 1955.

Štih, Peter, Vasko Simoniti. Na stičišču svetov. Ljubljana: Modrijan, 2009.

Tesnière, Lucien. Oton Joupantchitch. Paris: Les belles-lettres, 1931.

Zadravec, Franc. Zgodovina slovenskega slovstva VI. Maribor: Založba Obzorja, 1980.

Župančič. Oton. Zbrano delo VI. (Veronika Deseniška.) Ed. Joža Mahnič. Ljubljana: DZS, 1972. 45-223.

Župančič, Oton. Simpozij 1978. Ed. France Bernik. Ljubljana: Slovenska matica, 1979. 